Kyanite petrogenesis in migmatites: Resolving melting and metamorphic signatures

Stacy E. Phillips ${ }^{1,2^{*}}$, Tom W. Argles ${ }^{1}$, Clare J. Warren ${ }^{1}$, Nigel B.W. Harris ${ }^{1}$, Barbara E. Kunz ${ }^{1}$

${ }^{I}$ School of Earth, Environment and Ecosystems Sciences, The Open University, Milton Keynes MK7 $6 A A, U K$

${ }^{2}$ Current address: Department of Geography, Geology and Environment, University of Hull, Hull, HU6 7RX, UK

Keywords: Kyanite, Migmatite, Trace elements, LA-ICP-MS, Cathodoluminescence

*Feel free to contact lead author with any comments or feedback via

email: stacy.phillips1@open.ac.uk, or on Twitter: @Shtacy_Phillips

This manuscript has been submitted for publication in Contributions to Mineralogy and Petrology. This manuscript has not undergone peer review. Subsequent versions of this manuscript may have revised content. If accepted, the final version of this manuscript will be available via the 'Peer-reviewed Publication DOI' link on the righthand side of this webpage. Please feel free to contact any of the authors; we welcome feedback. 


\title{
Kyanite petrogenesis in migmatites: Resolving melting and metamorphic signatures
}

\author{
Stacy E. Phillips ${ }^{1,2^{*}}$, Tom W. Argles ${ }^{1}$, Clare J. Warren ${ }^{1}$, Nigel B.W. Harris ${ }^{1}$, Barbara E. Kunz ${ }^{1}$ \\ ${ }^{1}$ School of Earth, Environment and Ecosystems Sciences, The Open University, Milton Keynes MK7 \\ $6 A A, U K$
}

${ }^{2}$ Current address: Department of Geography, Geology and Environment, University of Hull, Hull, HU6 7RX, UK

*Corresponding author: stacy.phillips1@open.ac.uk

Keywords: Kyanite, Migmatite, Trace elements, LA-ICP-MS, Cathodoluminescence

\begin{abstract}
Aluminosilicates (kyanite, sillimanite and andalusite) are useful pressure-temperature (P-T) indicators that can form in a range of rock types through different mineral reactions, including those that involve partial melting. Their involvement in melting reactions means that the presence of aluminosilicates in migmatite mineral assemblages can help to (broadly) constrain the P-T conditions of melt formation, which then has implications for evaluating models of orogenic tectonics. Xenocrystic grains could lead to spurious tectonic interpretations, so being able to distinguish between different petrogenetic sources is important. Petrological and geochemical investigation of migmatite-hosted kyanite from Eastern Bhutan shows that kyanite petrogenesis may be constrained by combining information from morphology, cathodoluminescence response, microtextural position and geochemical zoning patterns. $\mathrm{Mg}, \mathrm{Ti}, \mathrm{Ca}, \mathrm{Fe}, \mathrm{Cr}$ and $\mathrm{Ge}$ concentrations provide diagnostic clues that distinguish sub-solidus kyanite from kyanite that crystallised directly from melt, or grew peritectically during muscovite dehydration reactions. The abundance of these elements in kyanite is also strongly controlled by protolith composition, with considerable inter-sample variation observed in this sample set. LA-ICP-MS maps, especially of $\mathrm{Cr} / \mathrm{V}$, provide additional information about changing geochemical environments during kyanite growth. These data and observations show that most kyanite is of xenocrystic origin in the analysed samples, and therefore that its presence does not necessarily constrain the P-T conditions of the melt reaction(s). This finding has significant implications for the interpretation of kyanite-bearing migmatites as representing early stages of melting during Himalayan evolution.
\end{abstract}




\section{Declarations}

Funding: This study was funded by the NERC CENTA Doctoral Training Partnership and a British Geological Survey CASE studentship awarded to Stacy Phillips.

Conflicts of interest/Competing interests (include appropriate disclosures): The authors declare that they have no conflict of interest.

Availability of data and material: The online version of this article contains supplementary material, which is available to authorized users.

Code availability: Not applicable

\section{Acknowledgments}

Research was funded by the NERC CENTA Doctoral Training Partnership and a British Geological Survey CASE studentship awarded to SEP. Thanks are given to Kinley, Tandin, Nyima, and the rest of the crew at Namsay Adventures for their fieldwork assistance in Bhutan. Michelle Higgins, Kay Knight, Giulia Degli Alessandrini, Sam Hammond, and Fran Jenner are thanked for their assistance in sample preparation and analysis. SEP thanks Eleni Wood for fruitful discussions throughout the project.

\section{Author Contributions}

Tom W. Argles, Clare J. Warren, and Nigel B. Harris contributed to the study conception and design as part of Stacy E. Phillips' PhD proposal. Sample collection, preparation, and analysis were performed by Stacy E. Phillips. Barbara E. Kunz provided substantial LA-ICP-MS assistance to Stacy E. Phillips, including trial and development of new analysis routines. The first draft of the manuscript was written by Stacy E. Phillips and all authors commented on previous versions of the manuscript. All authors read and approved the final manuscript. 


\section{Introduction}

Aluminosilicate phases are commonly used to broadly constrain P-T conditions reached by a wide range of metamorphic and anatectic rocks, i.e., high-P (kyanite), high-T (sillimanite), low-P (andalusite). In sub-solidus metasedimentary rocks, they can form through a variety of different discontinuous and continuous mineral reactions. During partial melting reactions and the subsequent formation of migmatites, aluminosilicates may form as the product of incongruent melting as peritectic products, may crystallise directly from melt, or may occur in melt portions as xenocrysts from the metamorphic source. Each petrogenesis therefore has different implications for the metamorphic evolution of the host rock.

The presence of a particular aluminosilicate phase plays a critical role in our interpretation of orogenic processes. For example, the presence of kyanite in Himalayan leucogranites is commonly interpreted as a sign of melting during prograde burial (Groppo et al. 2010; Iaccarino et al. 2015); by contrast, the more widespread sillimanite-bearing leucogranites are generally interpreted as forming during later melting related to decompression during exhumation (Harris and Massey 1994; Weinberg 2016). The location and age of granite bodies and migmatites containing either kyanite or sillimanite therefore underpins evolutionary models of Himalayan formation, providing evidence for prograde or retrograde melting. Constraining the petrogenetic history of kyanite in these rocks is therefore critical for constraining tectonic models of orogenic evolution in general, and models of Himalayan evolution in particular.

Kyanite can incorporate 100's-1000's $\mathrm{ppm}$ of $\mathrm{Fe}, \mathrm{V}, \mathrm{Cr}$ and $\mathrm{Ti}$ as well as lower concentrations of other trace elements (Pearson and Shaw 1960; Herz and Dutra 1964; Chinner et al. 1969; Albee and Chodos 1969; Neiva 1984; Yang and Rivers 2001; Deer et al. 2013). Recent studies have shown that kyanite zoning revealed by cathodoluminescence (CL) imaging can be linked to trace element concentrations, which in turn can help to constrain rock reaction histories (Schertl et al. 2004; Horkley et al. 2013; Müller et al. 2016; Kendrick and Indares 2017; Tarantola et al. 2019; Peterman et al. 2021). Cr and $\mathrm{Ti}$ are known to be CL activators while $\mathrm{Fe}$ is a known CL quencher (Wojtowicz 1991; Pagel et al. 2000; Habermann 2002; Gaft et al. 2005), and variations in these elements have been shown to correlate well with changes in CL intensity (Müller et al. 2003). In some cases, however this relationship is non-existent or is not clear, and other elements (such as V, Li, Ga) also show correlations to CL intensity (Horkley et al. 2013; Müller et al. 2016; Kendrick and Indares 2017; Peterman et al. 2021), suggesting a non-systematic relationship between trace element composition and zoning pattern revealed by CL.

CL imaging has proven powerful in revealing subtle details in trace element variations within 
kyanite (Kendrick and Indares 2017), particularly in comparison to X-ray mapping techniques that often cannot detect the commonly low trace element concentrations in kyanite (Yang and Rivers 2001; Horkley et al. 2013). CL imaging, however, is a qualitative technique. LA-ICP-MS mapping is a relatively new quantitative analytical technique that has been used to investigate chemical zonation in pyroxene, amphibole, and garnet (Ulrich et al. 2009; Ubide et al. 2015; Raimondo et al. 2017; George et al. 2018). LA-ICP-MS mapping of kyanite therefore offers the ability to produce high spatial resolution quantified images that can then be directly correlated to zoning patterns revealed by CL. Linking CL images to trace element concentrations yielded by LA-ICP-MS mapping potentially provides a powerful combination of information for constraining kyanite petrogenesis.

Here we characterise the petrographic and geochemical composition of kyanite grains in metapelitic migmatites in Eastern Bhutan (Fig. 1). This region provides good exposure of a sequence of kyanite-grade rocks over a thickness of hundreds of metres (Grujic et al. 2002). Changes in kyanite composition were investigated using a combination of optical petrography, CL imaging, electron microprobe spot analyses, LA-ICP-MS maps (the first instance of this technique being applied to kyanite), and LA-ICP-MS spot analyses. Our results show that kyanite records geochemically-distinct zones that can be linked to growth during sub-solidus, peritectic and suprasolidus reactions. The identification of xenocrystic kyanite suggests that the presence of kyanite alone does not necessarily constrain the P-T conditions of melt formation. This observation has tectonic implications for models of Himalayan evolution. 


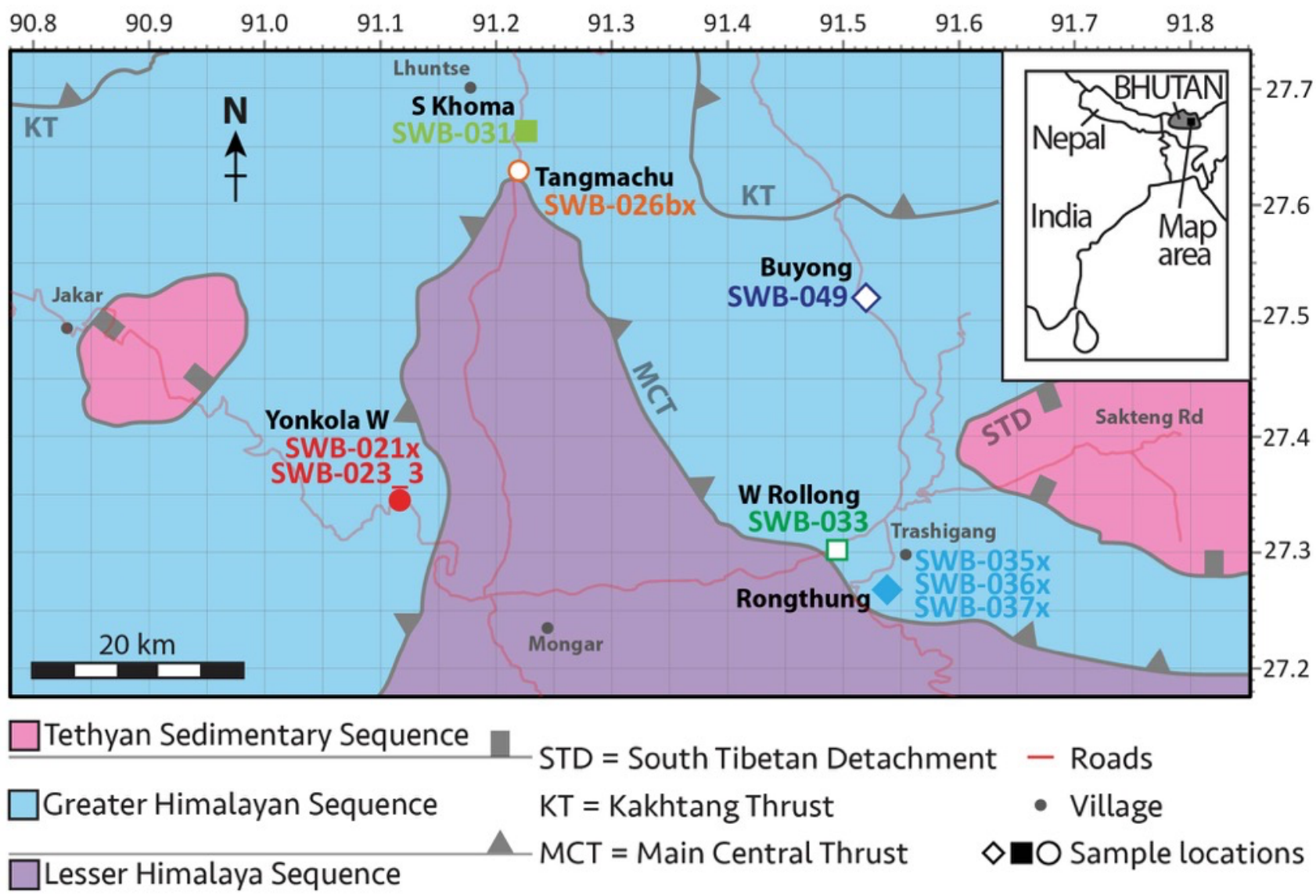

Fig. 1 Map of sample locations in E Bhutan. Colours for different sampling locations in this figure are used in figures throughout the rest of this paper. Redrawn after Greenwood et al. (2015). Map projection is WGS84, latitude and longitude given in decimal degrees. 


\section{Field relations}

Nine migmatite samples were collected from the Greater Himalayan Sequence (GHS) in six different locations in E. Bhutan (Fig. 1). All but one sample were collected within the structurally lowermost part of the unit, just above the Main Central Thrust (MCT); sample SPB-049i was collected from Buyong, a structurally higher locality within the GHS, below the out-of-sequence Kakhtang Thrust.

Samples were collected from migmatites containing deformed $\mathrm{cm}$-sized leucosomes (Fig. 2a). There was no field evidence of melt migration beyond the outcrop scale, for example from dykes, veinlets or feeder channels cross-cutting the foliation. Some leucosomes were boudinaged but were concordant with the foliation of the host schists. Kyanite was present in both the leucosome and the schist, with crystals ranging in size from $<1 \mathrm{~cm}$ up to $4 \mathrm{~cm}$ (Fig. 2b).

The schistose portions of the migmatites (paleosome) contain biotite + muscovite + quartz + feldspar + kyanite \pm garnet \pm tourmaline. The quartzo-feldspathic regions (interpreted as leucosome) typically also contain muscovite + biotite + kyanite in varying proportions. Minor amounts of Kfeldspar \pm garnet \pm tourmaline are present in some samples. The amount of biotite present in the leucosome varies between samples (Fig. 3). In some samples a distinctive biotite-rich \pm garnet \pm tourmaline restite is present, caused by the segregation of the melt-derived leucosome (e.g., SPB023_3). In other samples, alongside portions of the paleosome are $\mathrm{cm}$-sized rafts of biotite \pm garnet schlieren. Melanosome-leucosome contacts may be sharp in some samples (e.g., SPB-031), or much more diffuse and harder to distinguish elsewhere (e.g., SPB-033). In some samples (e.g., SPB-049i) the biotite schlieren become more disaggregated, with individual biotite grains distributed throughout the leucosome. The schlieren are interpreted to have originated in the host schist and then to have become variably entrained in, and later disaggregated by, the melt. Full sample descriptions can be found in the Online Resource S1 . 

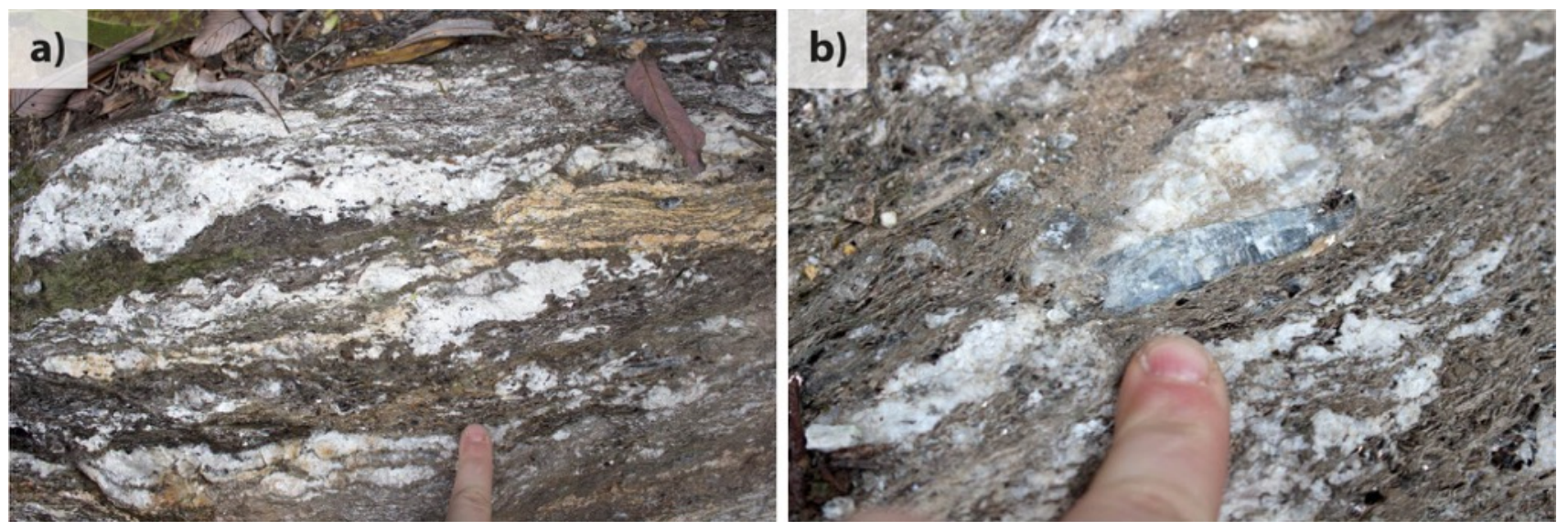

Fig. 2 Example of kyanite-bearing migmatite from E Bhutan. (a) Typical outcrop at Yonkola West with irregular leucosome lenses in a kyanite-bearing schist. (b) Kyanite crystal at the margin between a leucosome lens and host schist.

\section{Distinct restite Schlieren development}

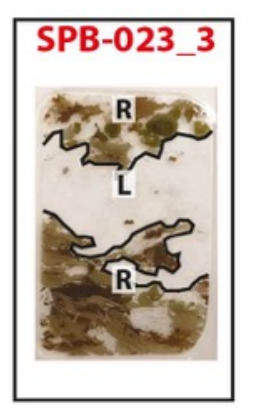

$\underline{\text { Location }}$

Yonkola

Tangmachu

Khoma

W Rollong

Rongthung

Buyong
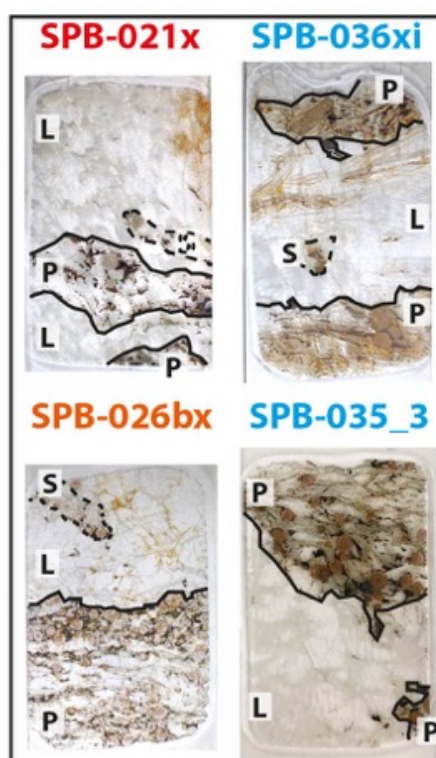
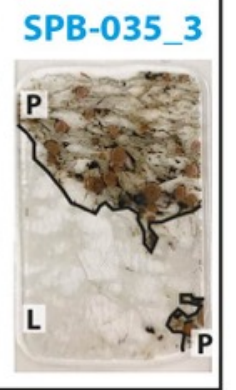

Biotite distributed throughout

Sharp contact Diffuse contact

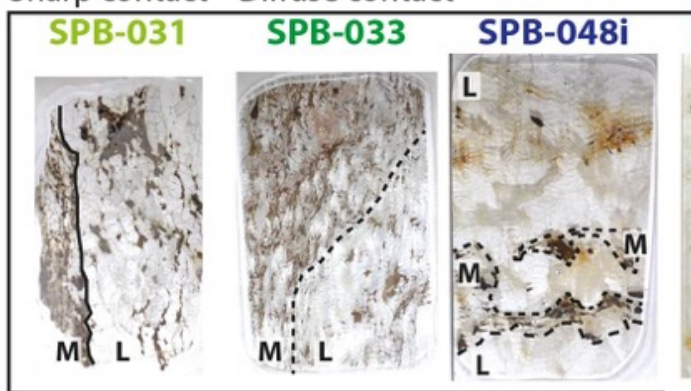

- Sharp contact

......Unclear/diffuse contact

$\mathbf{L}=$ Leucosome

$\mathbf{S}=$ Schlieren

$\mathbf{M}=$ Melanosome

$\mathbf{P}=$ Paleosome

$\mathbf{R}=$ Restite

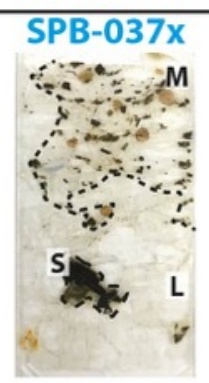

SPB-049i
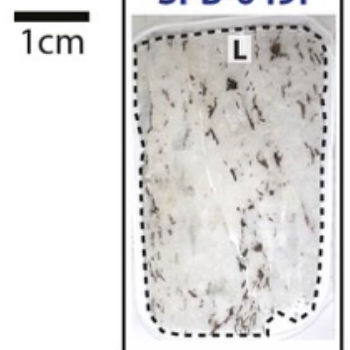

Metatexites Increasingly segregated

Diatexites

Increased breakup of melanosome into schlieren layers

Fig. 3 Overview of variation in types of migmatite samples across E Bhutan, classified by the degree of segregation and distribution of biotite schlieren. 


\section{Methods}

Thin sections were made from each of the samples to carry out optical petrography. All other analyses were carried out on $100 \mu \mathrm{m}$-thick polished sections to preserve textural context.

\section{Cathodoluminescence imaging}

Greyscale panchromatic CL images were taken using a FEI Quanta 200 3D FIB-SEM equipped with a Centaurus Cathodoluminescence Detector at The Open University, using a working distance of $\sim 13$ $\mathrm{mm}$ and either $3.3 \mathrm{nA}$ and $10 \mathrm{kV}$ or $1.0 \mathrm{nA}$ and $15 \mathrm{kV}$. Contrast and brightness settings were optimised for each analytical session, with the aim of highlighting internal variations in kyanite and reducing image noise. Where kyanite was in contact with strongly luminescent feldspars, brightness was reduced to stop excess feldspar luminescence affecting and washing out the kyanite luminescence. After acquisition, image brightness was adjusted manually using Adobe Photoshop. For large grains individual CL images were manually stitched together in Adobe Photoshop.

\section{Major element analyses}

Major element concentrations were measured on carbon-coated thick sections using the Cameca SX100 microprobe equipped with 5 wavelength dispersive spectrometers at The Open University. Each spectrometer was routinely calibrated and verified during each analytical session using a selection of in-house standards. Major element reproducibility was ensured by analysis of an inhouse secondary standard (Open University Garnet "NGA") at the start of each session and compared to long term trends (data collected for $>10$ years). Spectrometers used for the following elements were: PET - K, P, Ca, Ti, LIF - Fe, TAP - Si, Mg, Na, Al. Major element analyses were carried out using a standard silicate analysis setup of $20 \mathrm{nA}$ beam, $20 \mathrm{kV}$ accelerating current and 10 $\mu \mathrm{m}$ beam size, at a working distance $\sim 15 \mathrm{~mm}$. The following oxides were measured: $\mathrm{SiO}_{2}, \mathrm{TiO}_{2}$, $\mathrm{Al}_{2} \mathrm{O}_{3}, \mathrm{FeO}, \mathrm{MgO}, \mathrm{CaO}, \mathrm{Na}_{2} \mathrm{O}, \mathrm{K}_{2} \mathrm{O}, \mathrm{P}_{2} \mathrm{O}_{5}$, and $\mathrm{MnO}$. Analyses were discarded if oxide totals for kyanite were $<99 \%$.

\section{Trace element spot analyses}

Spot analyses of ${ }^{24} \mathrm{Mg},{ }^{27} \mathrm{Al},{ }^{29} \mathrm{Si},{ }^{39} \mathrm{~K},{ }^{43} \mathrm{Ca},{ }^{45} \mathrm{Sc},{ }^{49} \mathrm{Ti},{ }^{51} \mathrm{~V},{ }^{53} \mathrm{Cr},{ }^{55} \mathrm{Mn},{ }^{56} \mathrm{Fe},{ }^{60} \mathrm{Ni},{ }^{65} \mathrm{Cu},{ }^{66} \mathrm{Zn},{ }^{71} \mathrm{Ga},{ }^{74} \mathrm{Ge}$, ${ }^{90} \mathrm{Zr}$, and ${ }^{137} \mathrm{Ba}$ were collected using a Photon Machines Analyte G2 $193 \mathrm{~nm}$ excimer laser system, equipped with a HelEX II laser ablation cell coupled to an Agilent 8800 Triple Quadrupole ICP-MS at The Open University.

ICP-MS tuning for spot analyses was carried out on the NIST SRM 612 glass with a $50 \mu \mathrm{m}$ spot, $10 \mathrm{~Hz}, 3.63 \mathrm{~J} / \mathrm{cm}^{2}$ and a speed of $5 \mu \mathrm{m} / \mathrm{sec}$. Analyses were run using a fluence of $2.5 \mathrm{~J} / \mathrm{cm}^{2}$, a repetition rate of $10 \mathrm{~Hz}$, and a $50 \mu \mathrm{m}$ spot size. Sample analysis lasted $30 \mathrm{~s}$, with $30 \mathrm{~s}$ background measurement before the laser fired, and $40 \mathrm{~s}$ washout. Two analyses each of the NIST612 and BCR 
standards bracketed every 20 unknowns.

Data reduction of spot analyses was carried out using Iolite software (Paton et al. 2011). BCR was used as the primary standard for $\mathrm{Mg}, \mathrm{Ca}, \mathrm{Ti}, \mathrm{Mn}$ and Fe. NIST SRM 612 was used as the primary standard and BCR-2G as the secondary standard for all other elements. ${ }^{29} \mathrm{Si}$ was used as the internal standardisation element using values either from microprobe analyses carried out adjacent to LA-ICP-MS spots, or average $\mathrm{SiO}_{2}$ concentrations measured by microprobe for each individual kyanite grain.

In order to assess data accuracy and precision, BCR-2G analyses were compared to published values (Jenner and O’Neill, 2012) and long term laboratory averages (Online Resource S2). Trace/major element concentrations measured by LA-ICP-MS maps/spots and electron microprobe were also compared for consistency (Online Resource S3).

\section{Trace element mapping}

Quantitative maps of ${ }^{29} \mathrm{Si},{ }^{51} \mathrm{~V},{ }^{53} \mathrm{Cr}$ and ${ }^{74} \mathrm{Ge}$ were collected in thirteen kyanite grains from eight different samples using the LA-ICP-MS system at The Open University as described above. Mapping was achieved by moving the sample stage continuously underneath a fixed laser beam at a given speed with a fixed spot size, allowing signals to be split into pixels from which compositional data can be extracted. The Teledyne Aerosol Rapid Introduction System (ARIS) was used to provide fast signal transport and washout rates. The He-carrier gas flow was tuned to produce optimal peak separation. Counting times were ${ }^{29} \mathrm{Si}=0.003 \mathrm{~ms},{ }^{51} \mathrm{~V}=0.0210 \mathrm{~ms},{ }^{53} \mathrm{Cr}=0.0180 \mathrm{~ms}$ and ${ }^{74} \mathrm{Ge}=$ $0.0240 \mathrm{~ms}$, giving a total sweep time of $80 \mathrm{~ms}$. Tuning was carried out using a laser beam masked into a $10 \mu \mathrm{m}$ square at $50 \mathrm{~Hz}$, a fluence of $3.63 \mathrm{~J} / \mathrm{cm}^{2}$ and a fixed speed of $30 \mu \mathrm{m} / \mathrm{sec}$ on the NIST SRM 612 glass. Mapping was carried out using a $10 \mu \mathrm{m}$ square at $150 \mathrm{~Hz}$, a laser fluence of 2.9 $\mathrm{J} / \mathrm{cm}^{2}$, using a fixed dosage of either 12 or 15 shots per pixel and a scan speed of 125 or $100 \mu \mathrm{m} / \mathrm{sec}$ respectively. For some large grains (e.g., SPB-049i_Ky07, Online Resource Fig. S5.12) a $20 \mu \mathrm{m}$ square size was used. Parallel lines were positioned directly below the previous line (i.e., $10 \mu \mathrm{m}$ below for $10 \mu \mathrm{m}$ squares) using the same scanning direction (left to right) to ensure the same particle transport properties of each ablation. The NIST SRM 612 glass was used as a primary standard, by analysing four lines before and after each map.

Map data reduction was carried out using HDIP LA-ICP-MS imaging software (Teledyne Cetac). Quantification of count maps was carried out using ${ }^{29} \mathrm{Si}$ as the internal standard element based on the average Si concentrations for each individual kyanite grain as measured by electron microprobe. Standardised data were then imported into XMapTools to facilitate the production of the maps (Lanari et al. 2014). Raw Si counts were used to identify kyanite and masks were applied to 
LA-ICP-MS maps in order to exclude other phases analysed in the scan. A 2-pixel median filter was applied to all exported map images to reduce noise but maintain visibility of textural features (see Lanari 2019).

\section{Results}

\section{Kyanite types from petrography}

Optical petrography revealed five different types of kyanite (Ky-A to Ky-E) distinguished by their microstructural positions and morphology (Fig. 4). Many samples contained multiple kyanite types (See Table 1). Ky-A and Ky-B are large, tabular, stable (no evidence of resorption or alteration at crystal edges) kyanite crystals, present in the schist and leucosome respectively (Fig. 4a and Fig. 4b). Ky-C grains are corroded and surrounded by large single grains of muscovite; they are present only in leucosomes (Fig. 4c). Ky-D are rare thin prismatic crystals present in some leucosomes (Fig. 4d). Ky-E are present in the leucosome and have an irregular poikiloblastic texture, often form in clusters of crystal, and contain abundant large inclusions of rutile and quartz (Fig. 4e).

Table 1 - Kyanite types observed in E Bhutan for each sample studied.

\begin{tabular}{|l|l|c|c|c|c|c|}
\hline \multirow{2}{*}{ Location } & \multicolumn{1}{|c|}{ Sample } & \multicolumn{5}{c|}{ Kyanite Type } \\
\cline { 3 - 7 } & & Ky-A & Ky-B & Ky-C & Ky-D & Ky-E \\
\hline Yonkola & SPB-021x \& SPB-021xii & $\mathrm{x}$ & $\mathrm{x}$ & $\mathrm{x}$ & $\mathrm{x}$ & \\
\hline Yonkola & SPB-023 & $\mathrm{x}$ & $\mathrm{x}$ & & & \\
\hline Tangmachu & SPB-026bx & $\mathrm{x}$ & $\mathrm{x}$ & & & \\
\hline S Khoma & SPB-031 & & $\mathrm{x}$ & & $\mathrm{x}$ & $\mathrm{x}$ \\
\hline W Rollong & SPB-033 & $\mathrm{x}$ & $\mathrm{x}$ & $\mathrm{x}$ & & \\
\hline Rongthung & SPB-035x \& SPB-035xii & $\mathrm{x}$ & $\mathrm{x}$ & $\mathrm{x}$ & $\mathrm{x}$ & \\
\hline Rongthung & SPB-036x & & $\mathrm{x}$ & $\mathrm{x}$ & & \\
\hline Rongthung & SPB-037x & & $\mathrm{x}$ & $\mathrm{x}$ & & $\mathrm{x}$ \\
\hline Buyong & SPB-049 & & & & \\
\hline
\end{tabular}



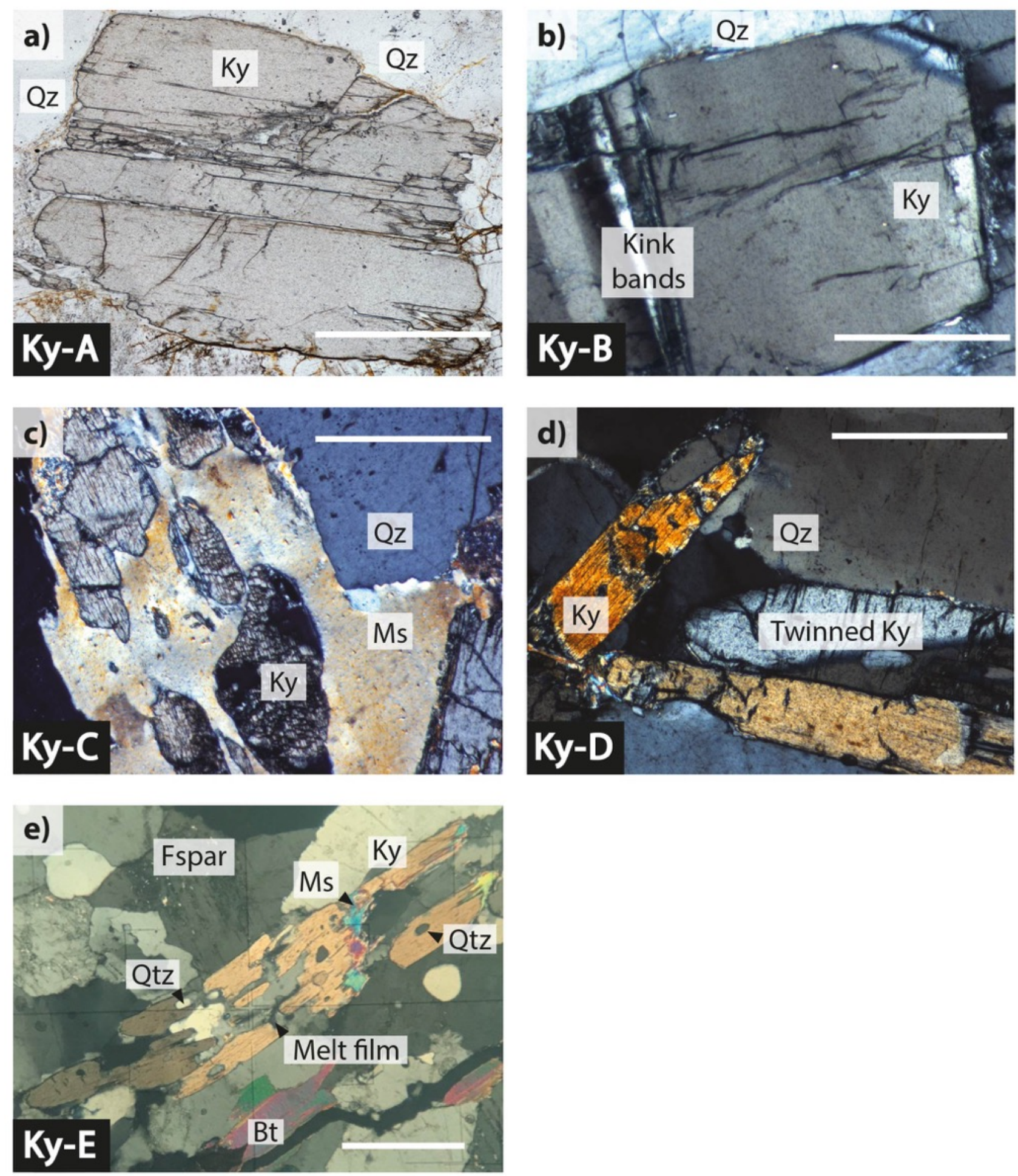

Fig. 4 Photomicrographs of different kyanite types. White scale bars are $500 \mu \mathrm{m}$. a) Ky-A: tabular kyanite grains in the schist (plane polarised light). b) Ky-B: tabular kyanite grains in the leucosome (crossed polarised light). c) Ky-C: corroded kyanite grains surrounded by muscovite in the leucosome (crossed polarised light). d) Ky-D: thin elongate kyanite grains found in the leucosome (crossed polarised light). e) Ky-E: poikiloblastic kyanite grains with rutile and quartz inclusions (crossed polarised light). Mineral abbreviations according to Whitney and Evans (2010). 


\section{Zone types from CL imaging}

Five different zoning patterns, here labelled Z1- Z5 (Table 2) were recognised in the CL images, with multiple zones commonly present in a single grain. Four of the five kyanite types, Ky-A, -B, -C and -E, show complex internal zoning patterns; Ky-D shows simpler plain patterns.

Table 2 - Classification of CL textures and zone types observed in different kyanite types. Colours for different zones in this table are used in figures throughout the rest of this paper. Note this colour scheme differs from that denoting sample locations (Fig. 1).

\begin{tabular}{|c|c|c|c|c|c|c|}
\hline \multirow{2}{*}{ CL texture } & \multirow{2}{*}{ Zone Type } & \multicolumn{5}{|c|}{ Kyanite Type } \\
\hline & & Ky-A & Ky-B & $\mathrm{Ky}-\mathrm{C}$ & Ky-D & Ky-E \\
\hline Sector zones & $\mathrm{Z} 1$ & $\mathrm{x}$ & $\mathrm{x}$ & & & \\
\hline Complex zones in kyanite core & $\mathrm{Z1}$ & $\mathrm{x}$ & $\mathrm{x}$ & $\mathrm{x}$ & & \\
\hline $\begin{array}{l}\text { Bright rims surrounding kyanite } \\
\text { core }\end{array}$ & $\mathrm{Z} 2$ & & $\mathrm{x}$ & $\mathrm{x}$ & & \\
\hline $\begin{array}{l}\text { Bright rims surrounding kyanite } \\
\text { core, truncated by crystal edge }\end{array}$ & $\begin{array}{l}\mathrm{Z} 2 \\
\text { (truncation) }\end{array}$ & & & $\mathrm{x}$ & & \\
\hline Plain zones & $\mathrm{Z3}$ & & & & $\mathrm{x}$ & \\
\hline Complex irregular zones & $\mathrm{Z} 4$ & & & & & $\mathrm{x}$ \\
\hline $\begin{array}{l}\text { Bright rims surrounding very } \\
\text { complex zones }\end{array}$ & $\mathrm{Z} 5$ & & & & & $\mathrm{x}$ \\
\hline
\end{tabular}

Z1 zones form the core of most kyanite grains (except Ky-D) and show complex, streaky, and patchy CL responses (Fig. 5a), occasionally in sectored segments. Coherent CL-response features are commonly discontinuous. Ky-A grains contain only Z1 zones.

Z2 zones form rims on Z1 cores, identifiable by an abrupt change in CL intensity (Fig. 5b \& Fig. 5c). These rims are commonly brighter than the $\mathrm{Z} 1$ cores, but are occasionally darker. Discontinuous bright lines and zones observed around Z1 cores are also categorized as Z2. The boundary between $\mathrm{Z1}$ and Z2 zones generally mirrors that of the outer crystal shape in Ky-B. In Ky-C grains the Z1-Z2 boundaries are often truncated by the irregular edge of the crystal. Z2 rims are present in Ky-B grains; less commonly in $\mathrm{Ky}-\mathrm{C}$.

$\mathbf{Z 3}$ zones are typified by plainer, more muted patches of darker and lighter CL response. They are observed in Ky-D grains (primarily from SPB-021x, but also in SPB-031 and SPB-036x). Z3 does not show the complex internal features typified by Z1 (Fig. 5d).

$\mathbf{Z 4}$ is characterised by complex patterns of bright and dark patches. It is found in Ky-E grains only (found primarily in sample SPB-049, rarely in SPB-031; Fig. 5e), which contain inclusions of quartz and rutile. Ky-E grains are typically found in clusters, and the complexity in CL textures also makes 
identification of zone boundaries difficult, meaning zones are often discontinuous. There are also discrete patches within (what appear to be) the same crystal, possibly indicating the presence of subgrain domains.

Z5 zones form discontinuous rims on Z4 and are characterised by a plain, bright-CL response (Fig. $5 e)$.
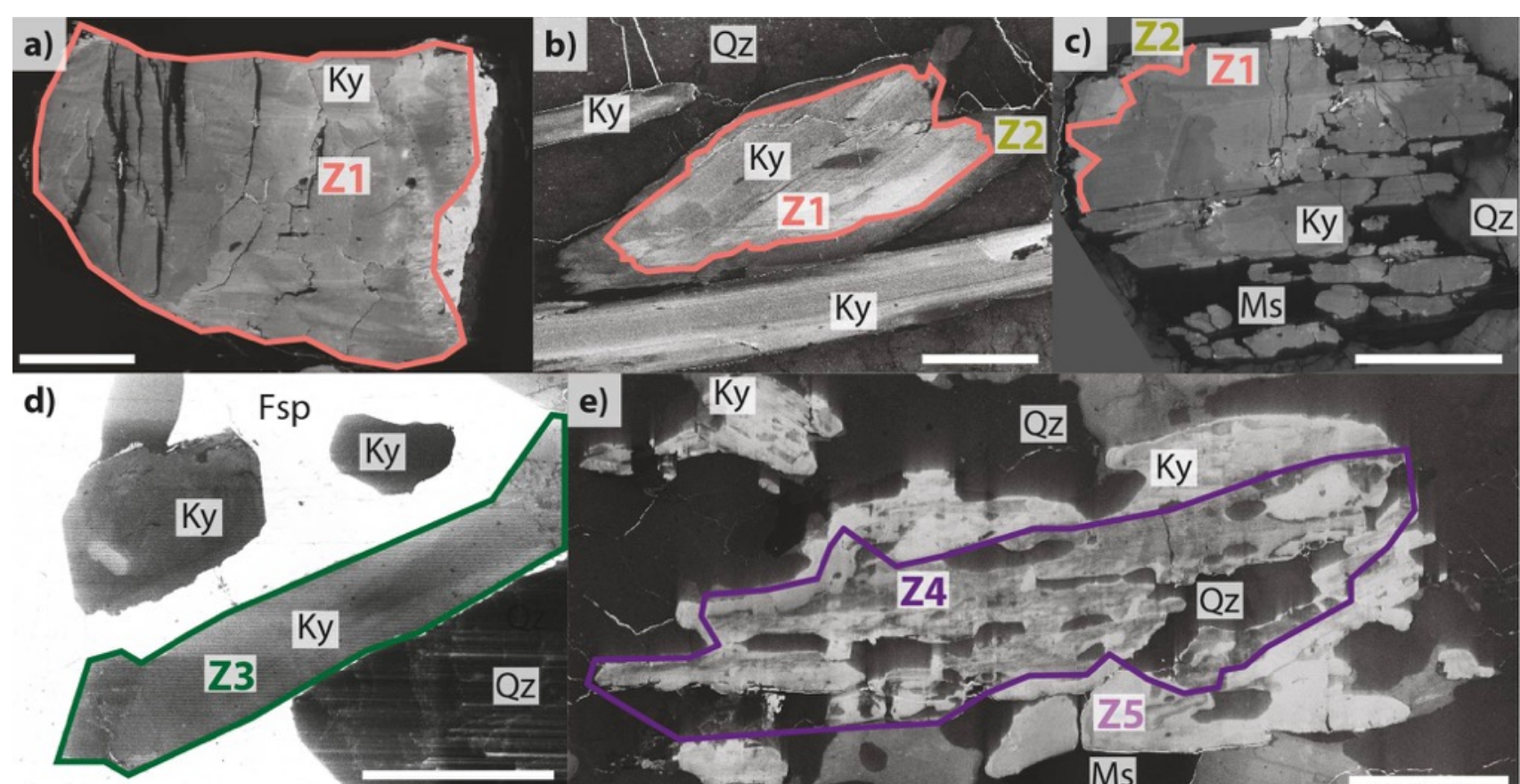

Q

\section{Ky}
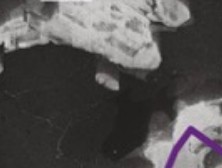

Ky
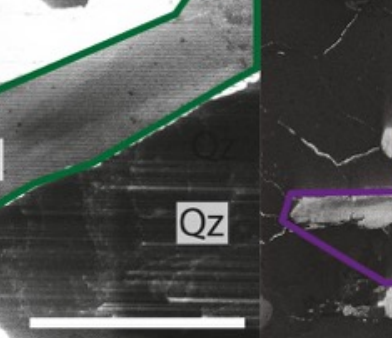

Qz

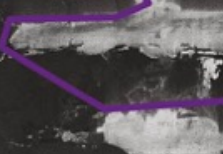

Fig. 5 Representative cathodoluminescence images of observed kyanite zone types (Z1-Z5). White scale bars are $500 \mu \mathrm{m}$. Mineral abbreviations according to Whitney and Evans (2010). 


\section{Trace element concentrations}

Trace element concentrations were measured for all zone types in 63 kyanite grains from 10 samples. Multiple spots were analysed on individual grains, with a total of 227 LA-ICP-MS spots analysed. Full data tables are included in Online Resource S4. The variability in trace element concentrations within and across different samples is shown in Fig. 6. Average 2 SE errors for measurable elements are also shown in Fig. 6. Ti ( 7-105 ppm), V ( 20-110 ppm), Cr ( 3-2850 ppm), Fe (520-6200), Ga $(\sim 19-48 \mathrm{ppm})$ and $\mathrm{Ge}(\sim 2-17 \mathrm{ppm})$ concentrations were above limits of detection in all grains. Ca $(\sim 100-1000 \mathrm{ppm})$ and Sc $(\sim 0.15-4 \mathrm{ppm})$ concentrations were measurable in most grains from all samples. 35 grains across all samples, except SPB-031 and SPB-033, contained measurable amounts of $\mathrm{Mn}(\sim 0.26-3 \mathrm{ppm})$.

$\mathrm{V}$ and $\mathrm{Ti}$ concentrations are similar across all zones ( $\sim 25 \mathrm{ppm}$ and $\sim 65 \mathrm{ppm}$ respectively). Average Sc concentrations increase progressively from $\sim 0.4-0.7 \mathrm{ppm}$ from $\mathrm{Z} 1$ to $\mathrm{Z} 4$, with average concentrations of $1.6 \mathrm{ppm}$ in $\mathrm{Z} 5$. Ge concentrations in $\mathrm{Z} 1, \mathrm{Z} 2$ and $\mathrm{Z3}$ average $\sim 6 \mathrm{ppm}$ and $\sim 8 \mathrm{ppm}$ in Z4 and Z5. Z4 and Z5, which are largely restricted to sample SPB-049, contain elevated Cr, Fe and Sc. Z5 rims yield a narrower range of concentrations for all elements compared with other zones. $\mathrm{Mn}$ is present in all zones but is more abundant in $\mathrm{Z} 1$ and $\mathrm{Z4}$ zones where concentrations vary strongly between $\sim 0.2-3 \mathrm{ppm}$. In Z3 zones Mn concentrations are lower and commonly <1 ppm.

\section{Trace element concentration variations}

All kyanite types and zones were mapped to reveal changes in the trace element concentrations. Key features are shown here on selected maps (Fig. 7); all mapped grains are documented in Online Resource S5. Comparisons between LA-ICP-MS maps and individual spot analyses are given in Online Resource S6.

The maps show that $\mathrm{V}, \mathrm{Cr}$ and Ge concentrations vary considerably in individual kyanite grains and between the different zone types. Si concentrations do not vary within the analytical uncertainty, making it an appropriate standardising element. Within a given grain $\mathrm{V}$ concentrations typically vary between 20-150 ppm, Cr between 20-200 ppm (can be up to $2500 \mathrm{ppm}$ in $\mathrm{Cr}$-enriched samples SPB-033 and SPB-049i), and Ge between 0-15 ppm, similar ranges to that observed in the LA-ICP-MS spot data. Variations in elemental concentrations can be patchy or abrupt, in a similar manner to the CL intensity variations. $\mathrm{Cr}$ and $\mathrm{V}$ concentrations in particular show abrupt changes within grains (Fig. 7b and Fig. 7c). Variations in Ge concentrations are more subtle but, in some grains, concentrations increase towards the grain rim (Fig. 7c). 

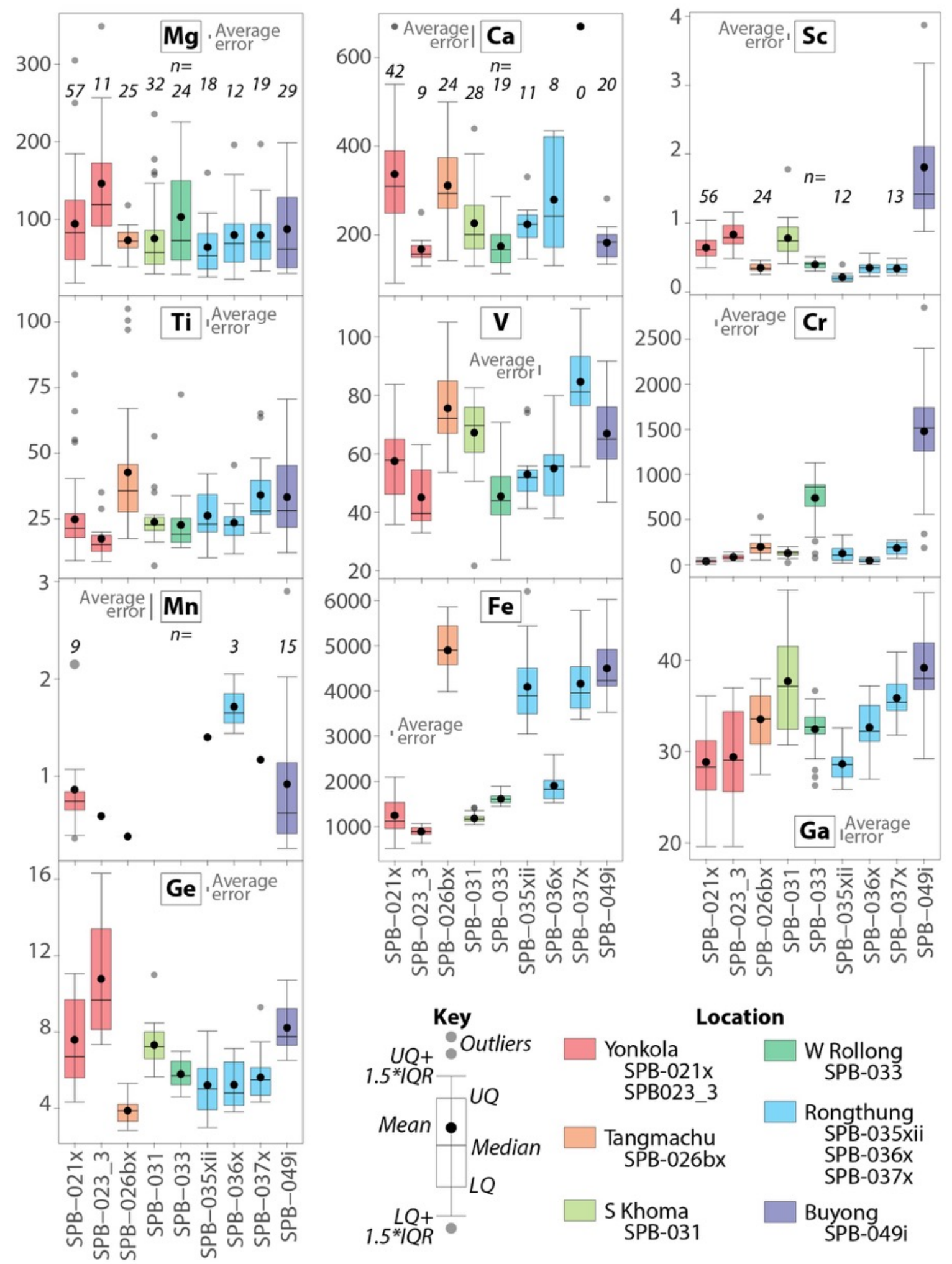

Fig. 6 Box and whisker plots of kyanite trace element concentrations (ppm) for each sample, colour coded by location. The number of analyses used for each plot is shown in the top left panel; exceptions are given for $\mathrm{Ca}, \mathrm{Sc}$, and $\mathrm{Mn}$ where not all analyses were above limits of detection. Average analytical uncertainty for each element are shown. UQ = Upper quartile, LQ = Lower quartile, IQR = Inter-quartile range (UQ - LQ). 

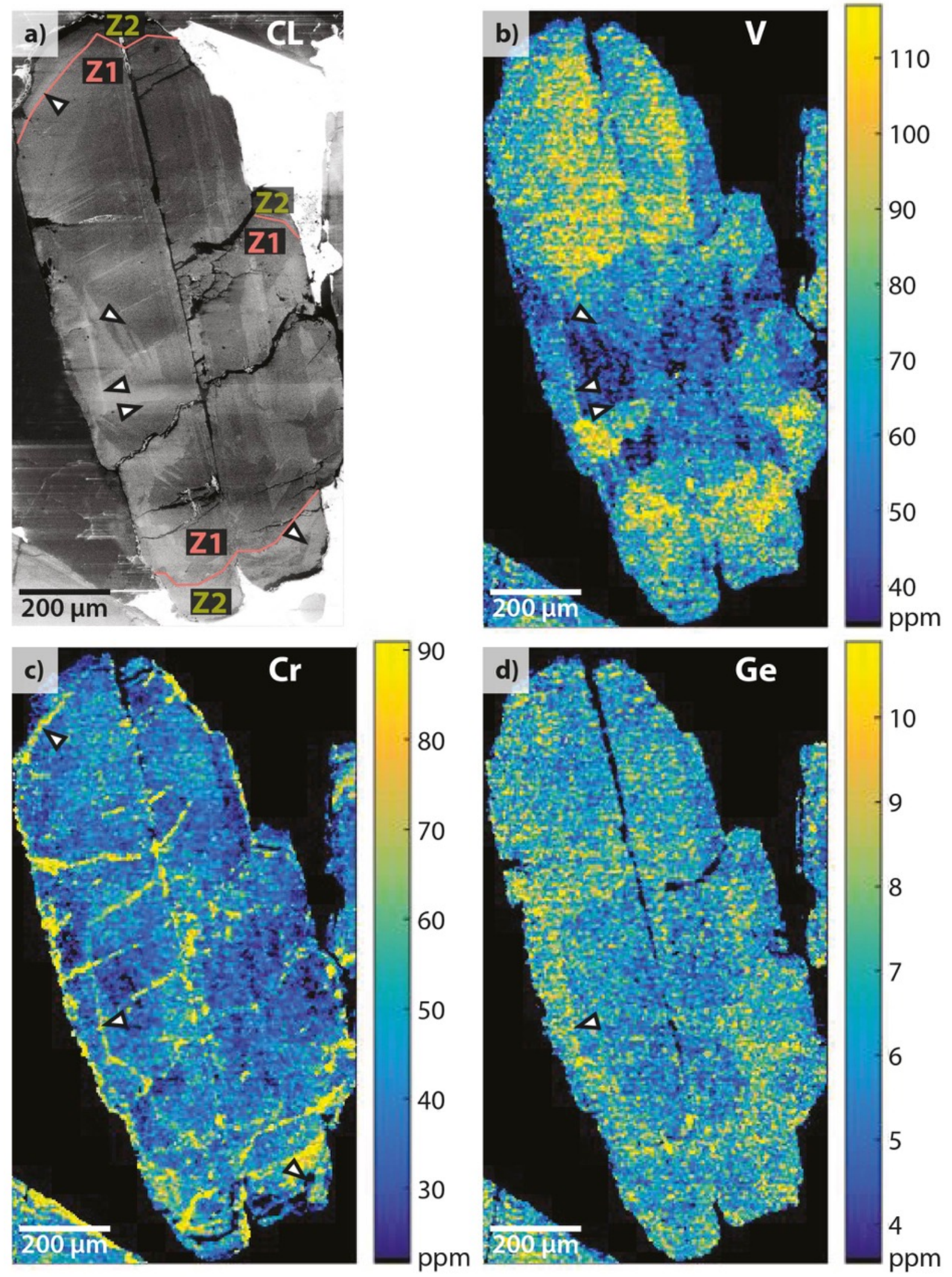

Fig. 7 a) Cathodoluminescence image showing different CL zones and b)-d) LA-ICP-MS trace element maps of SPB-021x_Ky06 grain. Arrows denote features visible in the CL image that are also present in the LA-ICP-MS maps. LA-ICP-MS maps are created in XMapTools and use an autocontrast scale, with concentrations in ppm, with a 2-median filter (See Lanari, 2019). 

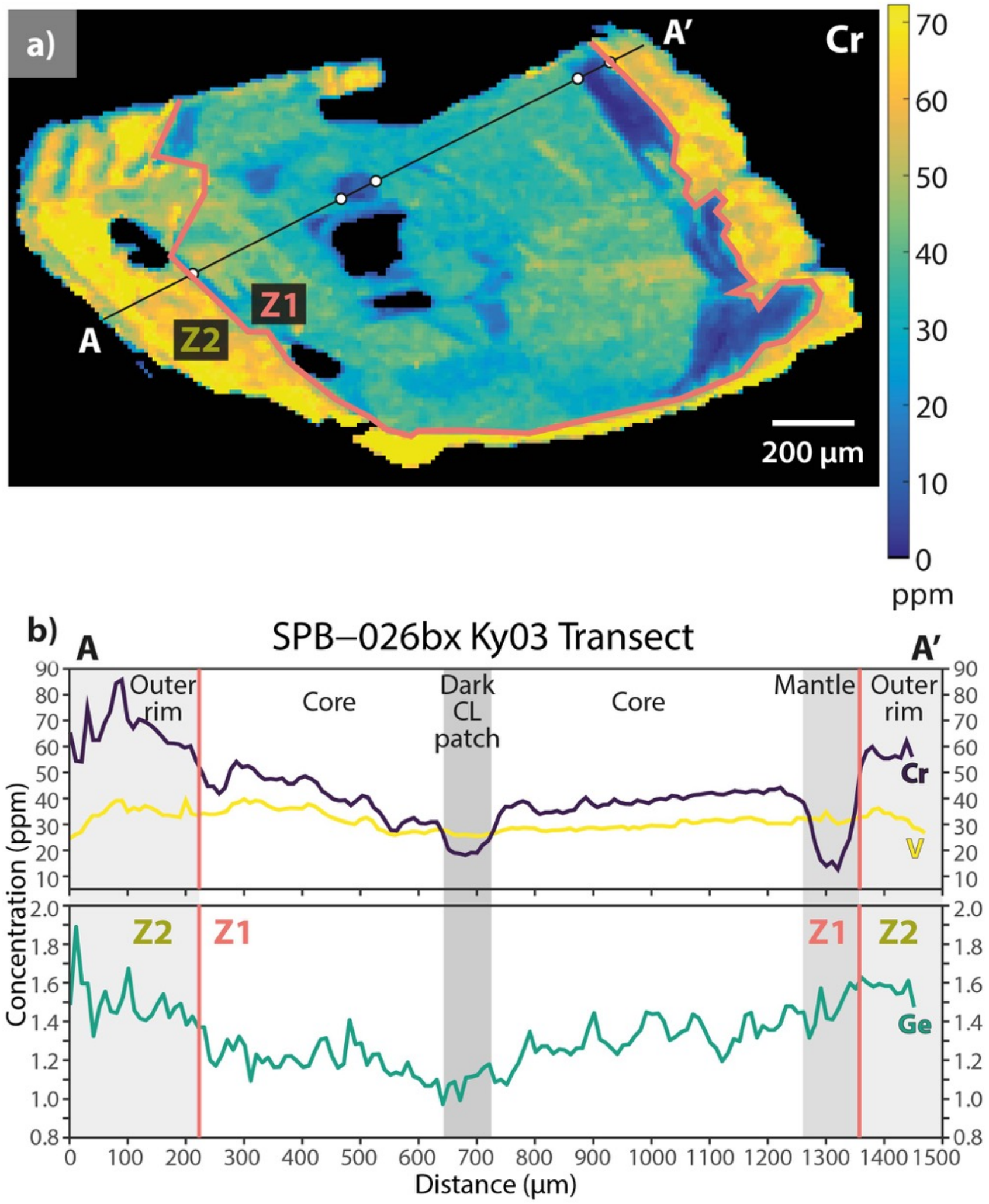

Fig. 8 a) LA-ICP-MS Cr map of grain SPB-026bx_Ky03 and b) transect (A-A') produced in XMapTools. 


\section{Discussion}

\section{Link between zoning patterns and trace element concentrations}

Kyanite grains in different samples show distinctive trace element concentrations, specifically in Fe, $\mathrm{Cr}$ and Sc (Fig. 6); kyanite in SPB-049i from Buyong for example has distinctively high concentrations of all these elements. This sample-to-sample variation is largely independent of kyanite type or zone type; for example, kyanite in sample SPB-026bx (Tangmachu) and samples SPB-035x, -035xii, -036x, -037x (all from Rongthung) include multiple different kyanite and zone types but all have significantly higher concentrations of Fe than other samples. This suggests that protolith composition controls abundances of some of the trace elements incorporates into kyanite (Fig. 6c, f, g).

To filter out the effect of differences in bulk composition and to facilitate cross-sample comparison, individual spot concentrations were normalised to the average concentration of that element in kyanite in that sample (Fig. 9). We recognise that usually concentrations are normalised to an average sample bulk concentration, but these samples are so heterogeneous that a bulk average would be meaningless here.

The normalised data suggest that the relative trace element compositions of $\mathrm{Z} 1$ and $\mathrm{Z4}$ are similar (Fig. 9), with no significant depletion or enrichment of any element. Z1 is strongly enriched in $\mathrm{Mn}$. Z2 and Z5 compositions are also similar to each other, both showing marked depletions in $\mathrm{Mg}$ and $\mathrm{Ti}$. Z3 is significantly enriched in Ge, slightly enriched in Sc and Ti, and slightly depleted in $\mathrm{Ca}, \mathrm{Mn}$, and Fe. Z5 is significantly depleted in Sc and slightly enriched in $\mathrm{Cr}$.

A distinctive absolute enrichment in Ge in $\mathrm{Z3}$ is particularly apparent in sample SPB-021x (Fig. 10a). However, two other samples (SPB-023_3 and SPB-031) that contain kyanite grains with Z3 zones show Ge concentrations comparable to those in Z1 and Z2 (Fig. 10b \& c). 


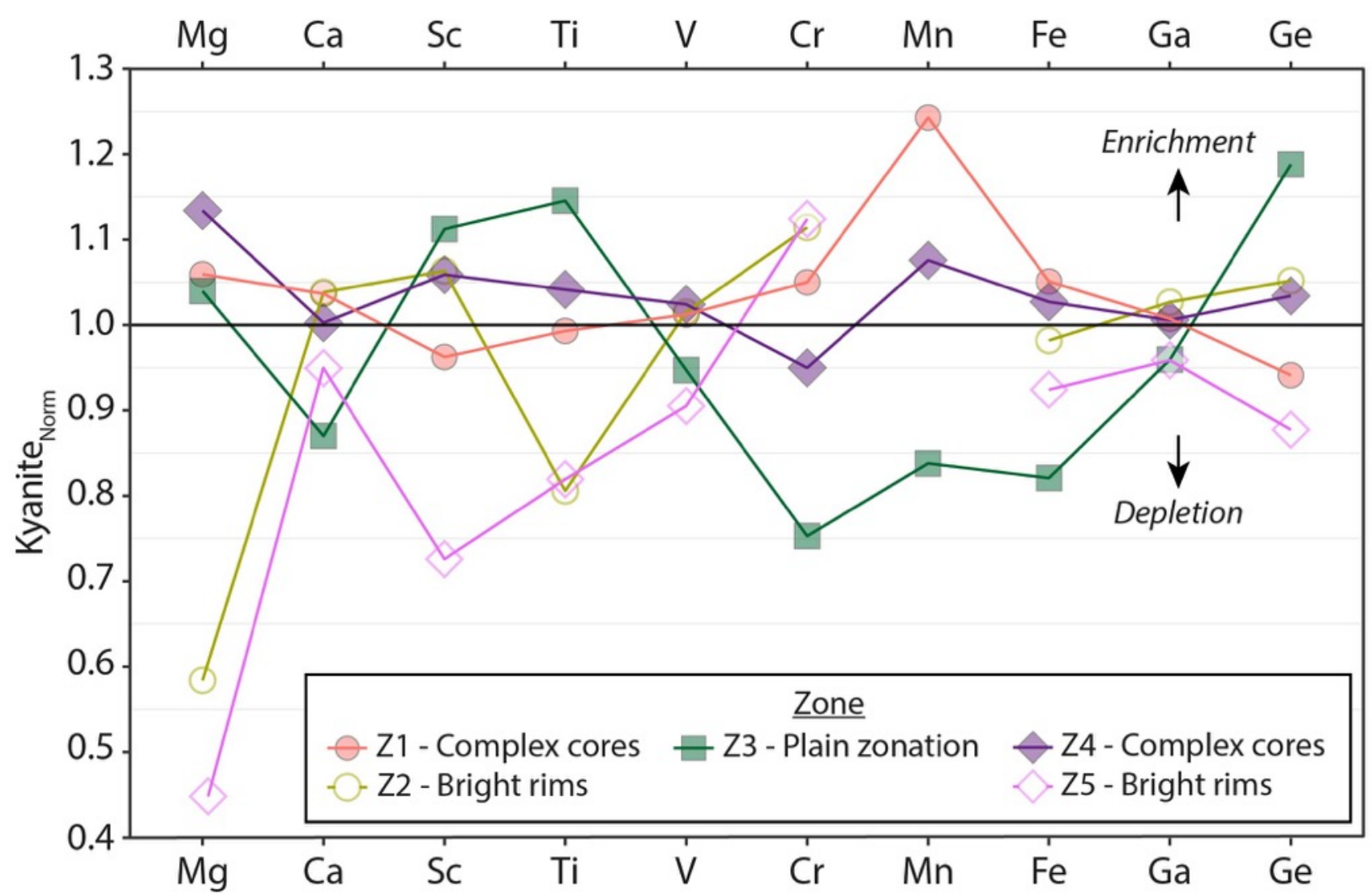

Fig. 9 Average normalised compositions of different kyanite zones. Data has been normalised to the average elemental composition of the kyanite in that sample. Note, Mn values are not plotted for Z2 and Z5 due to insufficient analyses (<3) with measurable Mn compositions.

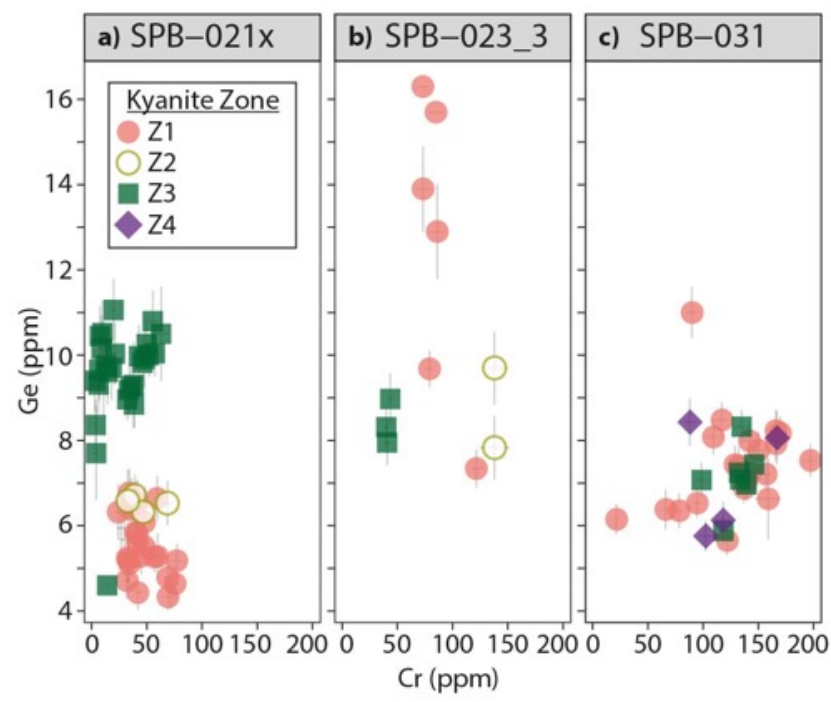

Fig. $10 \mathrm{Cr}$ vs Ge plots for samples that contain Z3 kyanite. 


\section{Link between CL response and trace element concentrations}

The LA-ICP-MS maps show that Z1 and Z4 are typified by variable concentrations of $\mathrm{Cr}, \mathrm{V}$ and Ge. The trace element maps of these zones show similar patchiness and sector zoning features to those recorded by CL (Fig. 6b). The Z2 and Z5 rims surrounding these Z1 and Z4 cores are typified by bright $\mathrm{CL}$ responses and an enrichment in $\mathrm{Cr}$. Z3 typically shows little change in $\mathrm{Cr}$, $\mathrm{V}$, or $\mathrm{Ge}$ concentrations.

Not all the features seen in CL are picked out by any of the maps of the individual trace elements. As expected from previous studies, changes in $\mathrm{Cr}$ concentration match well with $\mathrm{CL}$ variation: areas of high $\mathrm{Cr}$ correlated with areas brighter in CL. However, the $\mathrm{Cr}$ maps do not replicate all the features observed in $\mathrm{CL}$ (Fig. 7c). Here we find that maps of $\mathrm{Cr} / \mathrm{V}$ provide the best match to the CL patterns for all types of kyanite grains and for all zones (Fig. 11). This is somewhat surprising as V is not a known activator (Ramseyer and Mullis 2000), though it has been suggested as a luminescent centre in synthetic materials (Gaft et al. 2005).

It is clear from the $\mathrm{Cr} / \mathrm{V}$ maps described above that kyanite is able to record and preserve measurable $\mathrm{Cr} / \mathrm{V}$ changes throughout its growth history, both during sub-solidus conditions and when melt is present. What controls these changes is currently not well constrained however, and there is little to no published data relating to the cycling of $\mathrm{Cr}$ and $\mathrm{V}$ are cycled during metamorphism, melting and crystallization. Variations in $\mathrm{Cr} / \mathrm{V}$, as well as the other trace elements in kyanite, will be controlled by the phases growing or breaking down at any given time (garnet and rutile in particular for $\mathrm{Cr} / \mathrm{V}$ ), bulk rock element budgets, partition coefficients of trace elements in the melt, degree of partial melting, chemical equilibrium and disequilibrium processes during melting, and availability and composition of fluids. 


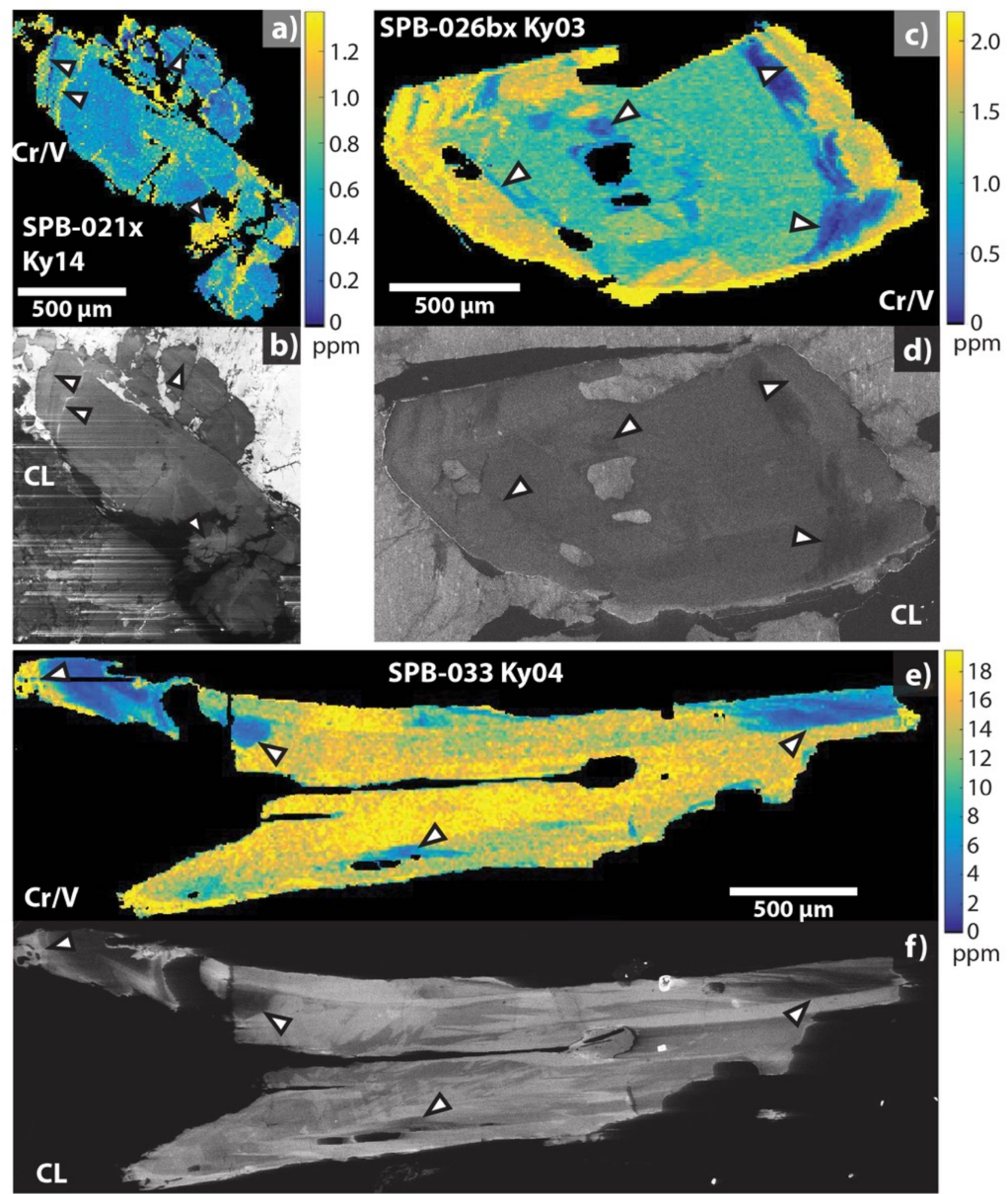

Fig. 11 Selected LA-ICP-MS maps of $\mathrm{Cr} / \mathrm{V}$ compared to $\mathrm{CL}$ images of the same grains. Arrows denote textural features that are observed in both LA-ICP-MS maps and CL images. Bright streaks from bright areas into darker areas are artefacts of imaging high-intensity phases/poorly polished surfaces. 


\section{Implications for kyanite growth}

Together, the petrographic observations and geochemical data suggest that kyanite may form as a product of multiple reactions during metamorphism and partial melting. Different observations and geochemical "fingerprints" allow the petrogenesis of the different grain and zone types to be discerned and identified.

\section{Ky-A grains and $\mathrm{Z1}$ zones: subsolidus growth}

Ky-A grains (containing only Z1), are found in the schists, suggesting they formed from sub-solidus metamorphic reactions (Fig. 12a). The complex patchy nature of these zones suggest they are likely to have formed via different continuous reactions during prograde metamorphism.

The complex patterns recorded in Z1 zones may relate to "chemomorphs" or ghost evidence of phases involved in previous reactions (Yang and Rivers 2001; Horkley et al. 2013; Kendrick and Indares 2017). Sector zoning in kyanite has rarely been described in the literature (Peterman 2021), but is a relatively common feature of $\mathrm{Z1}$ in our samples, visible in both the CL images and V concentration maps. Staurolite commonly displays sector zoning (Hollister 1970), and the crystallographic similarity of kyanite and staurolite would enable kyanite to inherit a zoning pattern from staurolite (Horkley et al. 2013). Although a reaction relationship between staurolite and kyanite has not commonly been recognised, a few examples have been described (Pattison and Spear, 2018).

\section{Ky-B and Ky-C grains: xenocrysts}

$\mathrm{Ky}-\mathrm{B}$ and $\mathrm{Ky}-\mathrm{C}$, found in the migmatitic leucosomes, contain Z1 cores. These cores suggest that Ky$\mathrm{B}$ and $\mathrm{Ky}-\mathrm{C}$ originally formed during sub-solidus reactions before being entrained into the melt, and that both $\mathrm{Ky}-\mathrm{B}$ and $\mathrm{Ky}-\mathrm{C}$ are the xenocrystic equivalents of $\mathrm{Ky}-\mathrm{A}$.

\section{$\mathrm{Z2}$ rims: growth from melt}

$\mathrm{Z} 2$ rims surround $\mathrm{Z} 1$ cores in $\mathrm{Ky}-\mathrm{B}$ and $\mathrm{Ky}-\mathrm{C}$ grains in leucosomes. These rims are generally concentric, typically show bright CL responses and are distinctively enriched in Cr (Fig. 9). Their morphology, chemistry and structural position therefore suggest that Z2 represents syntaxial growth of kyanite from melt.

Chromium is concentrated in sub-solidus rocks in garnet, with abundances of the order of 100-1000s of ppm of Cr (Yang and Rivers 2001; Raimondo et al. 2017; George et al. 2018). Previous studies recording high-Cr rims on kyanite in granulite-facies rocks (Kendrick and Indares 2017) have suggested that the breakdown of garnet in the presence of melt is responsible for the enrichment in kyanite, which interpreted as crystallising from melt. This provides a feasible mechanism for the $\mathrm{Cr}$ enrichment observed in $\mathrm{Z} 2$ zones.

\section{Ky-C: reaction with melt}


Like $\mathrm{Ky}-\mathrm{B}, \mathrm{Ky}-\mathrm{C}$ is found in the leucosome and contains $\mathrm{Z} 1$ cores and $\mathrm{Z} 2$ rims. $\mathrm{Ky}-\mathrm{C}$ grains, however, have corroded margins that truncate both $\mathrm{Z} 1$ and $\mathrm{Z} 2$, and are surrounded by single large, optically-continuous grains of muscovite (Fig. 4c). Their ragged morphology suggests dissolution, possibly due to an under-saturation of $\mathrm{Al}$ in the melt. The surrounding muscovite suggests that $\mathrm{Ky}-\mathrm{C}$ represents Ky-B that has reacted with the melt in a reversal of the muscovite-dehydration reaction (i.e., a 'back reaction sensu stricto' as defined by Kriegsman (2001)); Melt $+\mathrm{Al}_{2} \mathrm{SiO}_{5}=\mathrm{Ms}+\mathrm{Qtz}+$ $\mathrm{Pl}+\mathrm{H}_{2} \mathrm{O}$.

\section{Ky-D and Z3: growth from melt}

$\mathrm{Ky}-\mathrm{D}$, found only in leucosomes, contains only Z3. The distinctive morphology, plain texture in the CL images and high Ge concentrations suggests a different petrogenesis from other grains and zones. The lack of inclusions in Ky-D suggests that they are not of peritectic origin (Erdmann et al. 2012; Cesare et al. 2015), while their euhedral shape is consistent with a crystal growing freely within a melt.

Unlike Z2, Z3 in some samples (though not all) shows a distinctive enrichment in Ge (Fig. 9, Fig. 10). The source of the Ge enrichment is unknown: no other studies report Ge concentrations in kyanite (or have appeared to have measured it). Ge is similar to Si as a Group 14 element with a $4^{+}$ valency, but it also has a similar ionic radius and ionic potential to Al (Railsback 2003). It is unclear whether $\mathrm{Ge}$ is substituting for $\mathrm{Si}$ or $\mathrm{Al}$ in the kyanite structure.

\section{Ky-E and Z4: peritectic growth}

Ky-E grains with Z4 zones are predominant in sample SPB-049i (Buyong) and contain plentiful inclusions of quartz (Fig. 4e). These inclusions suggest that Ky-E/Z4 formed peritectically from the muscovite dehydration reaction which produces quartz + aluminosilicates (Erdmann et al. 2012; Cesare et al. 2015); $\mathrm{Ms}+\mathrm{Qtz}+\mathrm{Pl}+\mathrm{H}_{2} \mathrm{O}=\mathrm{Melt}+\mathrm{Al}_{2} \mathrm{SiO}_{5}$. The presence of irregular quartz lenses interpreted to be pseudomorphs after melt along the kyanite grain boundaries suggests that Ky-E formed before the melt crystallised (Fig. 4e) (Sawyer 1999; Holness and Sawyer 2008; Holness et al. 2011; Vernon 2011).

Ky-E forms large crystals that occur in clusters, and CL textures suggest the presence of subgrain domains. This texture is consistent with suggestions that peritectic minerals form cotectic overgrowths that coalesce during continued growth to form large clusters (Erdmann et al. 2012). Continued growth of the minerals may lead to the development of chemical zonation, which may then be further modified over time by diffusive re-equilibrium (Erdmann et al., (2012), Fig. 14). The resultant chemical variation will then be dependent on the diffusivity of the trace elements within the peritectic phase. Differences in trace element mobility in kyanite may therefore be the cause of the 
complex CL patterns observed in Ky-E/Z4 grains (Horkley et al. 2013).

\section{$\mathrm{Z5}$ rims: growth from melt}

Similar to Z2 which overgrows on Z1, Z5 rims are found on Z4. Like Z2, Z5 forms concentric rims, typically shows bright CL responses, and are distinctively enriched in Cr compared to Z1, Z3 and Z4 (Fig. 9). Like Z2, we interpret Z5 to represent growth from melt, possibly following the breakdown of garnet.

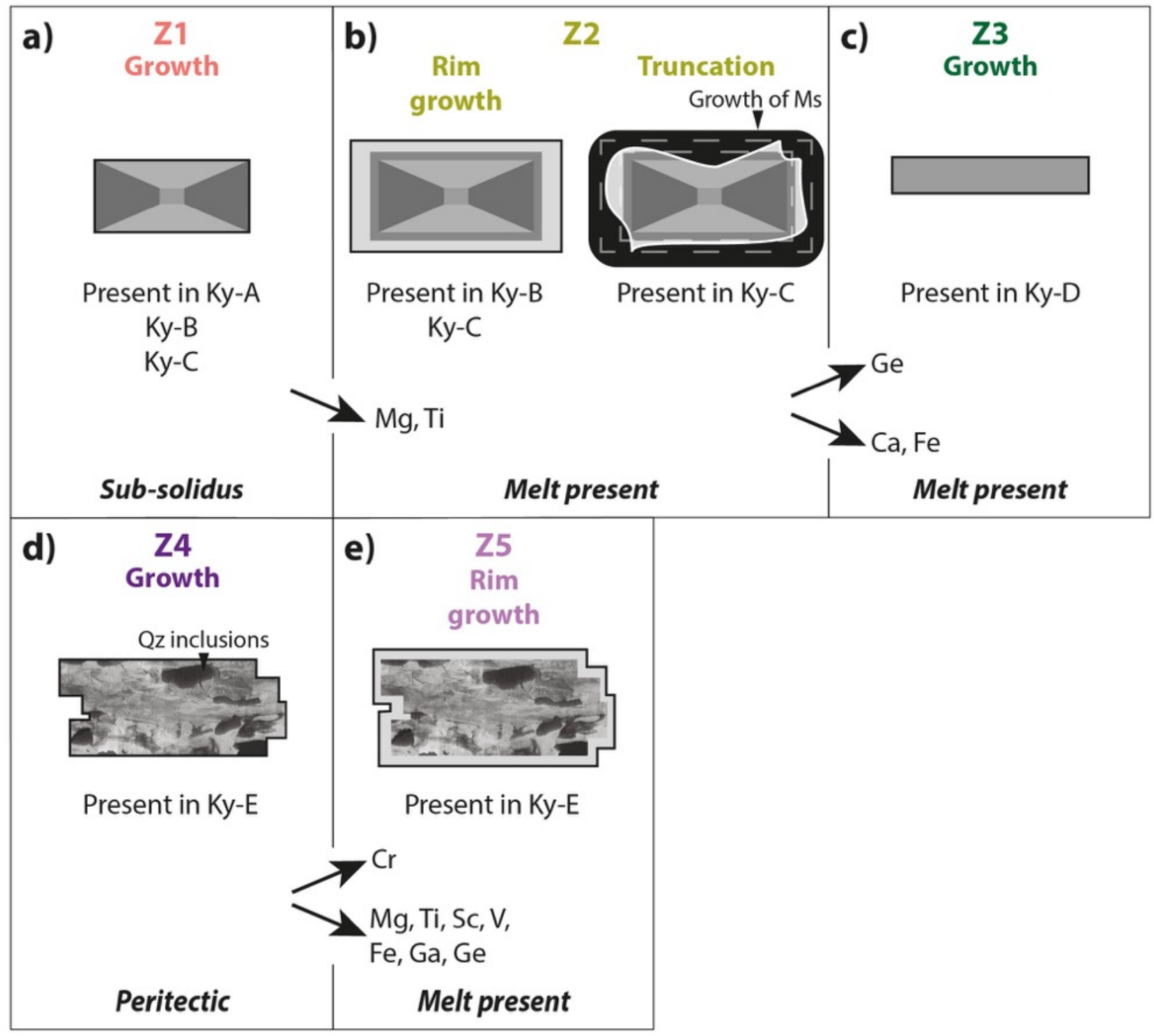

Fig. 12 Schematic cartoon showing how different kyanite types grow and how their CL patterns are preserved. Arrows represent relative increases or decreases in the elements shown between the different zones. Note that peritectic grains are only found in a few samples, whereas other kyanite types are more widespread. 


\section{Not all kyanite that forms from melt is the same}

Petrographic and geochemical data suggest that Z2, Z3 and Z5 all formed during melt crystallisation. However, Z3 is geochemically distinct from Z2 and Z5: it contains higher concentrations of Ge and lower concentrations of $\mathrm{Cr}$. Z3 is also petrographically different, forming elongate kyanite crystals rather than as epitaxial rims, further suggesting a distinct petrogenesis for Z3. We interpret Z3 to form as new grains crystallising in the melt, rather than Z2 and Z5 which form around existing grains.

Subtle depletions in $\mathrm{Ca}$ and $\mathrm{Fe}$ in $\mathrm{Z} 3$ could reflect progressive crystallisation of feldspars and biotite respectively, removing these elements from the melt. The cause for the higher Ge concentrations in $\mathrm{Z} 3$ is as yet unclear.

Partial melting of aluminous pelitic protoliths generates Al-rich melts that are capable of crystallising kyanite on cooling. Ky-D (Z3) grains in SPB-021xii are found in thin section within centimetres of $\mathrm{Z} 2$ growth on $\mathrm{Ky}-\mathrm{B}$ and $\mathrm{Ky}-\mathrm{C}$ grains, suggesting chemical disequilibrium in these melts on a small scale. The presence of corroded Ky-C grains near Ky-D suggests that the melt was Al-poor at the time Ky-C grains formed, yet Al-saturated when Ky-D formed. The leucosomes may therefore represent multiple generations of melt of different $\mathrm{Al}$ saturation, or changes in $\mathrm{Al}$ saturation over time.

\section{Protolith control on trace element concentrations in kyanite}

It has previously been suggested that kyanite compositions, especially with respect to $\mathrm{Cr}$ and $\mathrm{V}$, are strongly controlled by the protolith, with distinctive differences between kyanites formed in metasedimentary vs metabasaltic rocks (Müller et al. 2016). The source material for the Eastern Bhutan migmatites are GHS schists of sedimentary origin. Our data show that the $\mathrm{Cr}$ concentrations measured in our samples plot across all the fields delineated by the Müller et al., (2016) dataset (Fig. 13), not just the sedimentary field, suggesting that these elements may not provide useful source discriminators of the protolith, at least in the context of the Himalaya.

Variations in mineral assemblage and mineral mode will result in bulk compositional difference. Mineral assemblages are broadly similar across all samples, but some samples (specifically SPB-049i from Buyong, which shows higher concentrations of $\mathrm{Cr}$ in kyanite) lack garnet. $\mathrm{Fe}, \mathrm{Cr}$ and $\mathrm{Sc}$, which normally partition into garnet, may instead be preferentially incorporated into kyanite in this sample. The proportion of melt formed and extracted from each sample may also play a role in the elements that are hosted by kyanite, but quantification of this is beyond the scope of this study. 


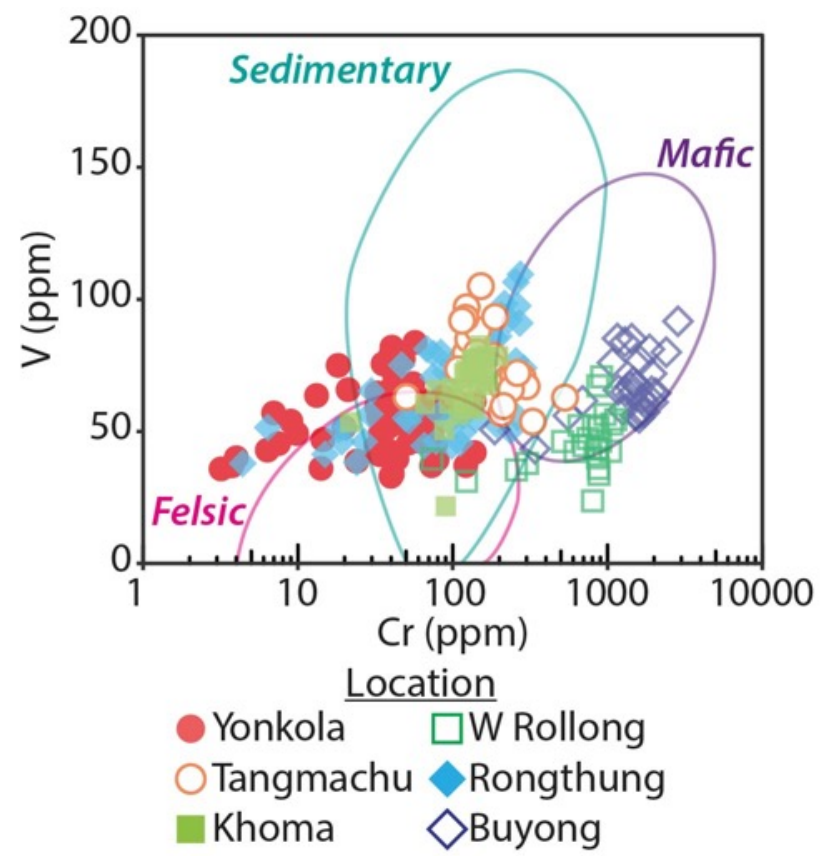

Fig. $13 \mathrm{~V}$ versus Cr compositions of Eastern Bhutan kyanite compared to those described in Müller et al., (2016). Coloured circles represent kyanite compositions in Müller et al., (2016) from felsic, sedimentary, and mafic source rocks. Eastern Bhutan data are colour-coded according to sample location.

\section{Implications for P-T determinations}

As a key pressure indicator mineral in metamorphic rocks, kyanite is useful for P-T constraints. However, our data show that not all kyanite is created equally. The majority of the kyanite cores (Z1) in our migmatitic samples are xenocrystic, and therefore place no constraints on the P-T conditions at which melting occurred or the melt crystallised. Any constraints instead come from the kyanite that did form in the presence of melt (Z2, Z3, Z4 and Z5). CL imaging and geochemical analyses are key for identifying kyanite that grew in the presence of melt, whether during peritectic reactions or directly crystallising from the melt. Constraining kyanite petrogenesis in this way is therefore crucial for subsequent interpretations of pressure and temperature based on the presence of aluminosilicates.

\section{Implications for Himalayan tectonics}

The samples in which kyanite grew via peritectic reactions or directly crystallised from melt (Yonkola SPB-021x, S Khoma SPB-031, Rongthung SPB-036x and Buyong SPB-049) provide evidence for prograde kyanite-grade melting in Eastern Bhutan. Such melts are implicated as key evidence for the "channel flow" model (Beaumont et al. 2001), whereby early melt-weakening of the GHS drove the change from burial to exhumation tectonics. Detailed geochronology is required to determine when the melt formed and hence to provide further tests of this model, and/or more recent 
composite tectonic models (Carosi et al. 2018). Combining geochronology with detailed information on petrogenesis is required to produce the accurate P-T-t paths that are critical for the evaluation of tectonic models in the Himalaya and other ancient orogens.

\section{Conclusions}

The presence of kyanite in granites or the leucosomes of migmatites does not necessarily imply that the kyanite grew in the presence of melt. Kyanite in migmatites from Eastern Bhutan formed through a variety of different mechanisms that may be distinguished by detailed petrographic observation, cathodoluminescence imaging and in-situ geochemical data;

- Sub-solidus kyanite is characterised by complex internal CL zoning visible in CL that is indicative of growth by continuous metamorphic reactions and the inheritance of textures from previous phases. The presence of this kyanite in both the host schist and the leucosome indicates entrainment of the kyanite into the melt.

- Peritectic kyanite, identifiable by the presence of quartz inclusions, also has complex internal zoning visible in CL, but is only found in the leucosome.

- Xenocrystic sub-solidus cores and peritectic kyanite are commonly surrounded by CL-bright rims, which are enriched in $\mathrm{Cr}$ and depleted in $\mathrm{Mg}$ and $\mathrm{Ti}$. These represent epitaxial kyanite growth on existing grains via crystallisation from the melt.

- Kyanite can crystallise directly from the melt, resulting in simple CL zoning patterns. These grains show a depletion in $\mathrm{Cr}$ and enrichment in $\mathrm{Sc}$, $\mathrm{Ti}$ and particularly $\mathrm{Ge}$, in comparison to other kyanite types.

Our data also show that kyanite records changes in its chemical environment as it grows, with particularly clear patterns picked out by the $\mathrm{Cr} / \mathrm{V}$ ratio. These results have implications for the interpretation of kyanite-bearing granitic rocks for constraining tectonic models of orogenesis. 


\section{References}

Albee AL, Chodos AA (1969) Minor element content of coexistent Al2SiO5 polymorphs. Am J Sci 267:310-316. https://doi.org/10.2475/ajs.267.3.310

Beaumont C, Jamieson RA, Nguyen MH, Lee B (2001) Himalayan tectonics explained by extrusion of a low-viscosity crustal channel coupled to focused surface denudation. Nature 414:738-742. https://doi.org/10.1038/414738a

Carosi R, Montomoli C, Iaccarino S (2018) 20 years of geological mapping of the metamorphic core across Central and Eastern Himalayas. Earth-Science Rev. 177:124138. https://doi.org/10.1016/j.earscirev.2017.11.006

Cesare B, Acosta-Vigil A, Bartoli O, Ferrero S (2015) What can we learn from melt inclusions in migmatites and granulites? Lithos 239:186-216. https://doi.org/10.1016/j.lithos.2015.09.028

Chinner GA, Smith J., Knowles C. (1969) Transition Metal Contents of Al2SIO5 Polymorphs. Am J Sci 267-A:96-113

Deer WA, Howie RA, Zussman J, et al (2013) Kyanite. In: An Introduction to the Rock-Forming Minerals. Mineralogical Society of Great Britain and Ireland, pp 193-196

Erdmann S, Scaillet B, Kellett DA (2012) Textures of peritectic crystals as guides to reactive minerals in magmatic systems: New insights from melting experiments. J Petrol 53:2231-2258. https://doi.org/10.1093/petrology/egs048

Gaft M, Reisfeld R, Panczer G (2005) Modern Luminescence Spectroscopy of Minerals and Materials. Springer-Verlag

George FR, Gaidies F, Boucher B (2018) Population-wide garnet growth zoning revealed by LAICP-MS mapping: implications for trace element equilibration and syn-kinematic deformation during crystallisation. Contrib to Mineral Petrol 173:74. https://doi.org/10.1007/s00410-018$1503-0$

Greenwood L V., Argles TW, Parrish RR, Harris NBW (2015) The geology and tectonics of central Bhutan. J Geol Soc London 2015-2031. https://doi.org/10.1144/jgs2015-031

Groppo C, Rubatto D, Rolfo F, Lombardo B (2010) Early Oligocene partial melting in the Main Central Thrust Zone (Arun valley, eastern Nepal Himalaya). Lithos 118:287-301. https://doi.org/10.1016/j.lithos.2010.05.003

Grujic D, Hollister LS, Parrish RR (2002) Himalayan metamorphic sequence as an orogenic channel: Insight from Bhutan. Earth Planet Sci Lett 198:177-191. https://doi.org/10.1016/S0012$821 \mathrm{X}(02) 00482-\mathrm{X}$

Habermann D (2002) Quantitative cathodoluminescence (CL) spectroscopy of minerals: Possibilities 
and limitations. Mineral Petrol 76:247-259. https://doi.org/10.1007/s007100200044

Harris NBW, Massey J (1994) Decompression and anatexis of Himalayan metapelites. Tectonics 13:1537-1546. https://doi.org/10.1029/94TC01611

Herz N, Dutra CV (1964) Geochemistry of some kyanites from Brazil. Am Mineral 49:1290-1305 Hollister LS (1970) Origin, Mechanism, and Consequences of Compositional Sector-Zoning in Staurolite. Am Mineral 55:742-766

Holness MB, Cesare B, Sawyer EW (2011) Melted rocks under the microscope: Microstructures and their interpretation. Elements 7:247-252. https://doi.org/10.2113/gselements.7.4.247

Holness MB, Sawyer EW (2008) On the pseudomorphing of melt-filled pores during the crystallization of migmatites. J Petrol 49:1343-1363. https://doi.org/10.1093/petrology/egn028

Horkley LKS, Spear FS, Ruscitto DM, Tailby ND (2013) The Secret Life of Kyanite. Geol Soc Am Abstr with Programs 96

Iaccarino S, Montomoli C, Carosi R, et al (2015) Pressure-temperature-time-deformation path of kyanite-bearing migmatitic paragneiss in the Kali Gandaki valley (Central Nepal): Investigation of Late Eocene-Early Oligocene melting processes. Lithos 231:103-121. https://doi.org/10.1016/j.lithos.2015.06.005

Jenner FE, O'Neill HSC (2012) Major and trace analysis of basaltic glasses by laser-ablation ICPMS. Geochemistry, Geophys Geosystems 13. https://doi.org/10.1029/2011GC003890

Kendrick J, Indares A (2017) The reaction history of kyanite in high-P aluminous granulites. J Metamorph Geol 36:125-146. https://doi.org/10.1111/jmg.12286

Kriegsman LM (2001) Partial melting, partial melt extraction and partial back reaction in anatectic migmatites. Lithos 56:75-96. https://doi.org/10.1016/S0024-4937(00)00060-8

Lanari P (2019) An introduction to XMapTools. User Guid. 2019-12-12

Lanari P, Vidal O, De Andrade V, et al (2014) XMapTools: A MATLAB(C-based program for electron microprobe X-ray image processing and geothermobarometry. Comput Geosci 62:227240. https://doi.org/10.1016/j.cageo.2013.08.010

Müller A, René M, Behr HJ, Kronz A (2003) Trace elements and cathodoluminescence of igneous quartz in topaz granites from the Hub Stock (Slavkovský Les Mts., Czech Republic). Mineral Petrol 79:167-191. https://doi.org/10.1007/s00710-003-0238-3

Müller A, van den Kerkhof AM, Selbekk RS, Broekmans MATM (2016) Trace element composition and cathodoluminescence of kyanite and its petrogenetic implications. Contrib to Mineral Petrol 171:70. https://doi.org/10.1007/s00410-016-1280-6

Neiva AMR (1984) Chromium-bearing kyanite from Mozambique. Mineral Mag 48:563-564. 
Non-peer reviewed EarthArXiv preprint (submitted to Contributions to Mineralogy and Petrology)

https://doi.org/10.1180/minmag.1984.048.349.18

Pagel M, Barbin V, Blanc P, Ohnenstetter D (2000) Cathodoluminescence in Geosciences: An Introduction. Cathodoluminescence Geosci 1-21. https://doi.org/10.1007/978-3-662-04086-7_1

Paton C, Hellstrom J, Paul B, et al (2011) Iolite: Freeware for the visualisation and processing of mass spectrometric data. J Anal At Spectrom 26:2508. https://doi.org/10.1039/c1ja10172b

Pearson GR, Shaw DM (1960) Trace elements in kyanite, sillimanite an andalusite. Am Mineral 45:808-817

Peterman EM, Jercinovic MJ, Beane RJ, de Wet CB (2021) Kyanite preserves prograde and retrograde metamorphic events as revealed by cathodoluminescence, geochemistry, and crystallographic orientation. J Metamorph Geol 1-24. https://doi.org/10.1111/jmg.12593

Railsback LB (2003) An earth scientist's periodic table of the elements and their ions. Geology 31:737-740. https://doi.org/10.1130/G19542.1

Raimondo T, Payne J, Wade B, et al (2017) Trace element mapping by LA-ICP-MS: assessing geochemical mobility in garnet. Contrib to Mineral Petrol 172:. https://doi.org/10.1007/s00410$017-1339-\mathrm{z}$

Ramseyer K, Mullis J (2000) Geologic Application of Cathodoluminescence of Silicates. In: Cathodoluminescence in Geosciences. Springer Berlin Heidelberg, pp 177-191

Sawyer EW (1999) Criteria for the recognition of partial melting. Phys Chem Earth, Part A Solid Earth Geod 24:269-279. https://doi.org/10.1016/S1464-1895(99)00029-0

Schertl H-P, Neuser RD, Sobolev N V., Shatsky VS (2004) UHP-metamorphic rocks from Dora Maira/Western Alps and Kokchetav/Kazakhstan: New insights using cathodoluminescence petrography. Eur J Mineral 16:49-57. https://doi.org/10.1127/0935-1221/2004/0016-0049

Tarantola A, Voudouris P, Eglinger A, et al (2019) Metamorphic and metasomatic kyanite-bearing mineral assemblages of thassos island (Rhodope, Greece). Minerals 9:252. https://doi.org/10.3390/MIN9040252

Ubide T, McKenna CA, Chew DM, Kamber BS (2015) High-resolution LA-ICP-MS trace element mapping of igneous minerals: In search of magma histories. Chem Geol 409:157-168. https://doi.org/10.1016/j.chemgeo.2015.05.020

Ulrich T, Kamber BS, Jugo PJ, Tinkham DK (2009) Imaging element-distribution patterns in minerals by laser ablation - Inductively coupled plasma - Mass spectrometry (LA-ICP-MS). Can Mineral 47:1001-1012. https://doi.org/10.3749/canmin.47.5.1001

Vernon RH (2011) Microstructures of melt-bearing regional metamorphic rocks. Mem Geol Soc Am 207:1-11. https://doi.org/10.1130/2011.1207(01) 
Weinberg RF (2016) Himalayan leucogranites and migmatites: Nature, timing and duration of anatexis. J. Metamorph. Geol. 821-843

Whitney DL, Evans BW (2010) Abbreviations for names of rock-forming minerals. Am Mineral 95:185-187. https://doi.org/10.2138/am.2010.3371

Wojtowicz AJ (1991) Luminescence of $\mathrm{Cr} 3+$ in kyanite. J Lumin 50:221-230. https://doi.org/10.1016/0022-2313(91)90046-X

Yang P, Rivers T (2001) Chromium and manganese zoning in pelitic garnet and kyanite: Spiral, overprint, and oscillatory (?) zoning patterns and the role of growth rate. J Metamorph Geol 19:455-474. https://doi.org/10.1046/j.0263-4929.2001.00323.x 


\section{ONLINE RESOURCES}

S1 Full sample descriptions

S2 LA-ICP-MS standard data

S3 Comparison between LA-ICP-MS trace element spot analyses and probe analyses

S4 Full LA-ICP-MS data table as a .xlsx

S5 LA-ICP-MS trace element maps

S6 Comparison between LA-ICP-MS trace element maps and spot analyses 


\section{S1 Full sample descriptions}

\section{SPB-021x (Yonkola)}

Sample SPB-021 $\mathrm{x}$ is a float sample comprised of a quartz + plagioclase + muscovite + biotite + kyanite + garnet schist and a quartz + plagioclase + K-feldspar + muscovite + kyanite granitic leucosome. The contact between the schist and granite is cuspate, and the schist is defined by the presence of biotite. This boundary is not always easy to define however, and grains near this boundary show evidence of interaction with melt. Occasional schlieren of biotite + garnet can be found in the leucosome. Rutile and ilmenite are found in both the schist and granite, but rutile is much less common in the granite.

Garnet is up to $0.5 \mathrm{~mm}$ in size and is typically strongly chloritized. When fresh crystals are preserved garnet cores are rich in quartz inclusions. Edges of biotite grains are also commonly chloritized. Muscovite can be found as small primary laths in both schist and leucosome, but more commonly, muscovite is found surrounding kyanite in the leucosome. When surrounding kyanite the muscovite is typically a single large optically-continuous grain. In the leucosome when muscovite is in contact with K-spar it commonly breaks down to quartz. Muscovite is rare in the schist and is only found in textural equilibrium surrounded by and intergrown with biotite. Undulose extinction and kinked grains are common features of kyanite, quartz, feldspar, and muscovite. Evidence of former melt includes embayments and blebs of quartz and K-feldspar and melt films.

\section{SPB-023_3 (Yonkola)}

Sample SPB-023 is an in-situ sample of a kyanite-bearing leucosome in a biotite-rich tourmaline host rock. The biotite + muscovite + quartz + plagioclase + tourmaline + kyanite host rock mineralogy varies in biotite mode, with some sections appearing more schistose, and others comprising almost exclusively of a kyanite + tourmaline + biotite restitic assemblage.

Tourmaline is present in both the leucosome and restite, is green in colour and often zoned, and contains abundant quartz inclusions. Tourmaline varies in size between $1 \mathrm{~mm}$ and $1 \mathrm{~cm}$, with smaller grains tending to be found in the leucosome. Kyanite is rare in the leucosome but when present it is large (cm-sized) and stable, although commonly is more rounded and is associated with muscovite at its edges. Large tourmaline grains may also be in close proximity to kyanite porphyroblasts. Inclusion trails or tourmaline and quartz in kyanite may preserve wavy fabric. Occasional trails of small kyanite grains are found in between large plagioclase grains. In the restite/schist, tabular rounded kyanite aggregations are found, often with biotite and tourmaline inclusions.

Large (up to $1 \mathrm{~cm}$ ) muscovite laths are common in the leucosome, but when in contact with large plagioclase grains reaction textures show skeletal muscovite + quartz. Muscovite in the schist is common and typically is seen to be breaking down irregularly-shaped quartz. Melt pseudomorphs may also be preserved within reactant muscovite. Biotite that is surrounding muscovite in the schist does not show this breakdown texture. Coarse $(\mathrm{cms}) \mathrm{K}$-feldspar porphyroblasts dominate and often contains elongate stringers of muscovite 
and quartz along cleavage planes and cracks. Zircon is largely confined to the schist, and monazite is rare. Zircon in the leucosome is usually found at grain boundaries between K-spar and quartz.

\section{SPB-026bx (Tangmachu)}

Sample SPB-026bx is composed of a quartz + plagioclase + muscovite + biotite + garnet + kyanite schist in contact with a quartz + plagioclase + muscovite + kyanite leucosome. The presence of biotite and garnet define the extent of the schist, but occasional biotite-garnet schlieren can be found in the leucosome. In the schist elongate muscovite laths and kyanite define the foliation, and garnet and kyanite tend to be found in separate layers parallel to foliation.

Garnet is up to $3 \mathrm{~mm}$ in size, commonly with quartz, ilmenite, and rutile inclusions in the core, with an inclusion-free rim. Smaller garnets $(<1 \mathrm{~mm})$ tend to be inclusion free. Garnet tends to be surrounded by biotite, some grains of which are now chloritized. Occasional staurolite grains up to $2 \mathrm{~mm}$ in size are preserved in between adjacent garnet grains, but they are more commonly smaller and skeletal, breaking down to quartz. Kyanite in the schist can be up to $1 \mathrm{~cm}$ in size, and while often surrounded by thin rims of muscovite, it is considered to be stable. Ilmenite and rutile are both found in the schist matrix, zircon is also common.

In the leucosome tabular cm-sized kyanite is concentrated close to the margin with the schist, although some grains are found further away from this contact. Schlieren of biotite + muscovite + garnet can be found in the leucosome. Large primary muscovite laths are observed in the leucosome and tend to show breakdown to quartz when adjacent to K-feldspar. Fine grained muscovite is present in trails of quartz + sillimanite associated with the edges of large feldspar porphyroblasts. Bent twin planes in feldspars and kyanite, and strained quartz is common in the leucosome.

\section{SPB-031x (S Khoma)}

SPB-031 is a biotite + kyanite + quartz + feldspar schist with discontinuous patches of kyanite + quartz + feldspar leucosome. Garnet is not present in this thin section, though is observed in the field in the schist. Kyanite is primarily found in the leucosome, is cm-sized and elongate, as is associated with large, rounded quartz grains either as inclusions, or intergrowing with matrix grains. Occasional smaller, thinner kyanite grains have been observed. Cuspate margins between quartz and feldspars, strings-of-beads, and melt films all suggest the presence of melt in the leucosome. However, recrystallisation of quartz is common, and fine grained recrystallisation of quartz and plagioclase can be found between kyanite porphyroblasts. Large Kfeldspar porphyroblasts in the leucosome commonly have patches of perthitic texture, with wavy or deformed blebs. Ilmenite is a common inclusion in kyanite and biotite.

\section{SPB-033 (W Khoma)}

Sample SPB-033 comprises a schist (biotite + muscovite + kyanite + garnet + quartz + plagioclase assemblage) and a leucosome (quartz + plagioclase + K-feldspar + kyanite + garnet + muscovite assemblage) . 
Biotite and garnet-rich schlieren are common, and the contact between the melt and host rock can be hard to distinguish. The nature of the contact appears to be determined by the presence or absence of biotite and a coarsening of matrix minerals in the leucosome.

Two types of garnet are observed; small $(<\mathrm{cm})$ subhedral, inclusion free garnets are found primarily in the leucosome but are also found in biotite-bearing domains, and larger (up to $5 \mathrm{~mm}$ ), often more euhedral garnets found in the schist that quartz, biotite, and ilmenite inclusions.

Kyanite in the schist tends to be cm-sized, elongate, and oriented along biotite-defined foliation. Stable cm-sized tabular kyanite is found in the granite, as well as clusters of smaller mm-sized of tabularequant kyanite. Muscovite is present in both the schist and leucosome, commonly intergrowing with biotite, often being coarser in the latter. Quartz throughout the section shows chessboard extinction and elongate kyanite grains can show spectacular deformation textures. Rare tourmaline can be found associated with biotite in the schist. Ilmenite and rutile are present throughout in minor amounts but are more likely found in the schist.

\section{SPB-035xii (Rongthung)}

Sample SPB-035xii is a float sample comprising of a quartz + muscovite + biotite + kyanite + garnet + tourmaline schist. It is associated with a quartz + plagioclase $+\mathrm{K}$-feldspar + muscovite + kyanite granite leucosome present in sample SPB-035xi. The boundary between the schist and leucosome is defined by the presence of biotite + garnet, and a significant coarsening of matrix material in the leucosome. The schist contains significant muscovite versus biotite, and both micas are in textural equilibrium. Patches of irregularshaped and interlocking quartz are found between micaceous layers, with quartz often showing chessboard extinction. Garnet porphyroblasts in the schist are up to $3 \mathrm{~mm}$ in size, with inclusion rich cores of quartz, ilmenite, occasional muscovite, and rare tourmaline, with thin inclusion-free rims. Garnet often shows red Festaining, and biotite is often chloritized.

Kyanite in the schist is less abundant than in other samples but is tabular in form and its unresorbed margins suggest stability. Elongate $\mathrm{cm}$-sized kyanite are typical, but there are also smaller mm-sized stubby grains also. Sillimanite is present in the schist, occurring primarily at the margins edges of muscovite laths, but can also be seen at the edge of garnet grains, and in rare instances, is seen nucleating on kyanite. Rare, irregularly shaped staurolite can be found in the schist, alongside $<\mathrm{mm}$-sized tourmaline. Ilmenite and rutile are common throughout the schist.

\section{SPB-036x (Rongthung)}

Sample SPB-036x is a float sample comprising a quartz + muscovite + biotite + kyanite + garnet + tourmaline schist and a quartz + plagioclase $+\mathrm{K}$-feldspar + muscovite + kyanite granite leucosome. The schist is defined by the presence of foliated biotite + garnet; isolated layers of biotite + garnet schlieren are also found away from the main schist. Sections cut from this sample include varying amounts of schist: schlieren: 
leucosome. The schist contains equal amounts of muscovite and biotite, which is commonly chloritized. Subhedral garnet porphyroblasts are up to $4 \mathrm{~mm}$ in size, are inclusion rich with thin inclusion free rims, and are usually Fe-stained. The inclusion assemblage contains randomly oriented quartz (sometimes significantly larger mm-sized grains), muscovite, chlorite, rutile and ilmenite. In some garnet grains, rims show finegrained inclusion trails that are oriented along hexagonal crystal faces. Rare large mm-sized tourmaline can be found in the schist and schlieren.

Kyanite is not abundant in the schist and generally form small stable grains. More commonly, kyanite is very elongate (cms-long), parallel to the foliation in the schist, and is often found close to schlieren or in layers in the leucosome. Kyanite grains in the leucosome tend to be stable but are commonly bent. Kyanite grains surrounded by muscovite are also common, though these are usually more tabular in shape.

Minerals in the leucosome are coarser, with $\mathrm{cm}$-sized feldspar and quartz porphyroblasts. Finer grained quartz and plagioclase is commonly found between rounded porphyroblasts. Muscovite is primarily found surrounding ragged kyanite grains, but tabular muscovite laths are also observed. Occasionally, where muscovite is found next to K-feldspar muscovite is seen to break down to quartz.

\section{SPB-037x (Rongthung)}

Sample SPB-037x is a float sample comprising a quartz + muscovite + biotite + kyanite + garnet + tourmaline schist and a quartz + plagioclase + K-feldspar + muscovite + kyanite granite leucosome. SPB-037x is very heterogeneous; in places there is a poorly foliated kyanite-garnet-schist in contact with a coarse granite leucosome which is kyanite-bearing; elsewhere tourmaline clots are common in the granite, and biotite and garnet are distributed throughout the leucosome.

Garnets in the schist are subhedral and up to $2 \mathrm{~mm}$ in size, with cores containing primarily quartz and ilmenite inclusions with lesser amounts of rutile and muscovite, and inclusion free rims. They are commonly Fe-stained and surrounding micas are usually chloritized. Entirely chloritized biotite and muscovite is common throughout the rocks in both schist and leucosome, with chlorite further breaking down to complex quartz, muscovite, and ilmenite intergrowths. Feldspars throughout the leucosome are strongly sericitised. In a rare muscovite-rich patch in the leucosome an entire garnet grain and some muscovite grains have been pseudomorphed by chlorite. This patch also contains a number of small tourmaline clots that are not observed anywhere else in this sample.

Kyanite abundance is variable in its distribution throughout SPB-037x. Kyanite in the schist is generally stable (no evidence of resorption) with minor fine muscovite found at its margins. Grains can be elongate and up to $8 \mathrm{~mm}$ but they are randomly oriented within the schist. Many kyanite grains show undulose extinction and evidence of strain. At the poorly defined margin of the schist and leucosome there may be large stable kyanite grains, but kyanite is generally rare in the schist. When it is observed it is corroded in shape and surrounded by muscovite. 


\section{SPB-049i (Buyong)}

SPB-049 is a sample of kyanite leucogranite collected from the nose of a fold. It is considered to represent the leucosome of a migmatite, where biotite forms part of partly disaggregated schlieren from the surrounding host biotite schists. Hand specimen and thin/thick section photographs demonstrate the variability in the distribution of biotite and kyanite throughout the sample. Biotite and long elongate kyanite are found in broad layers that are likely the pre-existing foliation. Kyanite tend to be aggregated in the centre of the largest biotite-free leucocratic areas. Biotite is commonly chloritised, and rare muscovite is found alongside it in schlieren trails. Larger biotite aggregates are often overgrown by rutile clots (up to $1 \mathrm{~mm}$ in size). Most muscovite is found surrounding Type 3 kyanite. Quartz, plagioclase and partly sericitised K-feldspar comprise the leucogranite, with triple-point contacts being common, indicating the presence of former melt.

Kyanite abundance is varied and grains can be found in contact with biotite schlieren and as part of the leucosome. As well as Type 2 stable grains, and Type 3 reactant grains, other kyanite grains in this sample are distinctive. Most kyanite is large (often several centimetres in length) and contains numerous large, rounded inclusions of quartz \pm rutile; these are categorized as Type 6 kyanite. In some instances, these rounded quartz inclusions are rimmed by thin irregularly-shaped melt pseudomorphs in contact with kyanite. 


\section{S2 LA-ICP-MS standard data}

LA-ICP-MS analyses of kyanite were carried out over five analytical sessions. The majority of kyanite analyses were ran during July 2018 and May 2019, with some additional kyanite analyses in September 2019. Subtly different analytical conditions were used between these sessions with differences outlined in the above text. BCR-2G glass standard analyses measured during these sessions were compared to the preferred published values (Jenner and O'Neill, 2012) and are shown in Fig. S2.1 and in Table S2.1. BCR-2G was used as a primary standard for $\mathrm{Mg}, \mathrm{Ca}, \mathrm{Ti}, \mathrm{Mn}$ and $\mathrm{Fe}$, and therefore cannot be used as a secondary standard to check data quality on these elements. A quality check of Fe concentrations is given in Online Resource S3 where LA-ICP-MS spot analyses are compared to electron microprobe analyses.

BCR-2G is the best available secondary standard material in the absence of a certified kyanite standard, but it is not ideal for the verification of Ge concentrations. ${ }^{74} \mathrm{Ge}$ can have oxide interferences from $\mathrm{NiO}$ and $\mathrm{FeO}$, and doubly charged ${ }^{148} \mathrm{Nd}$ and ${ }^{148} \mathrm{Sm} . \mathrm{Ni}, \mathrm{Nd}$ and $\mathrm{Sm}$ are not present in kyanite, and interference from $\mathrm{FeO}$ in kyanite is deemed negligible here due to the minor abundance of ${ }^{58} \mathrm{FeO}$ and low oxide production in our LA-ICP-MS setup. Fe, $\mathrm{Nd}$ and $\mathrm{Sm}$ however may be present in sufficient amounts in BCR-2G and therefore could be causing interferences, resulting in the seemingly poor Measured/Preferred values shown in Fig. S2.1 and in Table S2.1. We therefore consider our kyanite Ge concentrations to be accurate despite discrepancies in the preferred values of $\mathrm{Ge}$ as measured in BCR-2G.

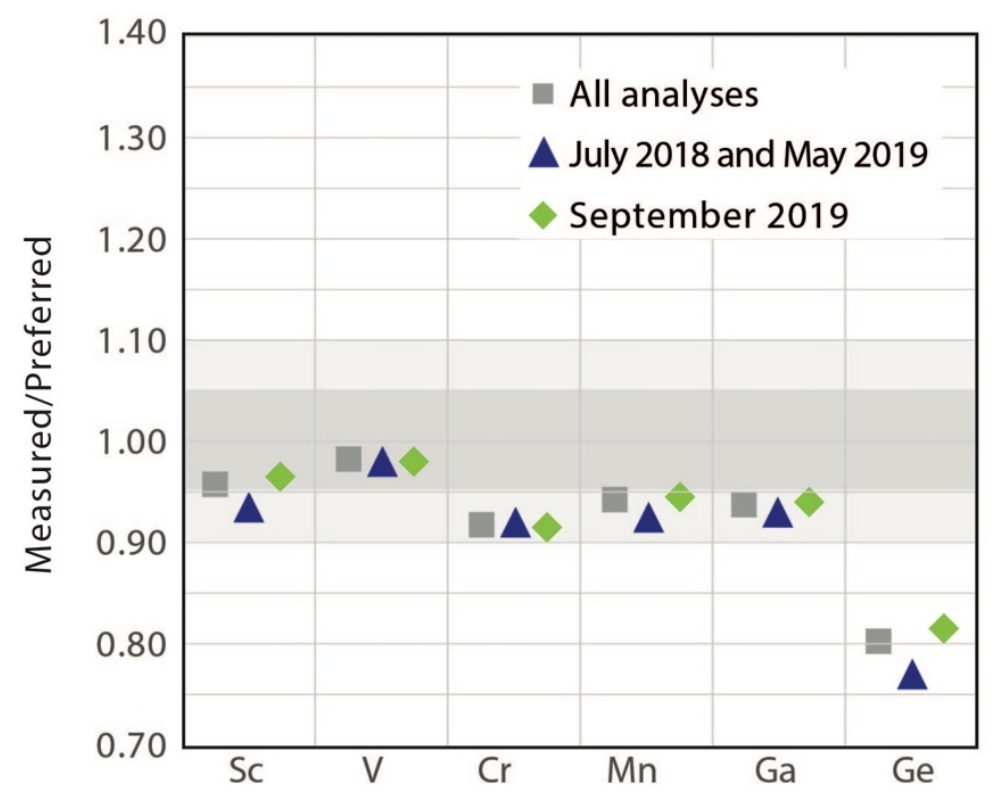

Fig. S2.1- Measured/Preferred values for BCR-2G secondary standard analyses from all LA-ICP-MS analytical sessions. Published values from Jenner and O'Neill, 2012. 
Table S2.1 - Average values of BCR-2G secondary standard analyses compared to published values. Published values from Jenner and O'Neill, 2012.

\begin{tabular}{|l|r|r|r|r|}
\hline & Preferred BCR ppm & $\begin{array}{c}\text { Mean BCR values } \\
(\mathrm{n}=68)\end{array}$ & SD & Measured/Preferred \\
\hline $\mathrm{Sc}$ & 34.36 & 32.82 & 0.99 & 0.95 \\
\hline $\mathrm{V}$ & 435.93 & 426.34 & 10.98 & 0.98 \\
\hline $\mathrm{Cr}$ & 17.25 & 15.79 & 0.87 & 0.92 \\
\hline $\mathrm{Fe}$ & 93600 & 99469.56 & 3011.80 & 1.06 \\
\hline $\mathrm{Ga}$ & 22.90 & 21.41 & 0.62 & 0.94 \\
\hline $\mathrm{Ge}$ & 1.81 & 1.45 & 0.14 & 0.80 \\
\hline
\end{tabular}




\section{S3 Comparison between LA-ICP-MS trace element spot analyses and probe analyses}

The BCR-2G data averages from individual analytical sessions matched well with published values, and long-term laboratory averages, with accuracy typically being around 5-7\% (see Online Resource $\mathrm{S} 2$ ). Good agreement was also found between Fe concentrations measured on the electron microprobe and by LA-ICP-MS at both high (>3000 ppm) and low ( $\sim 500$ ppm) concentrations (Fig. S3.1).

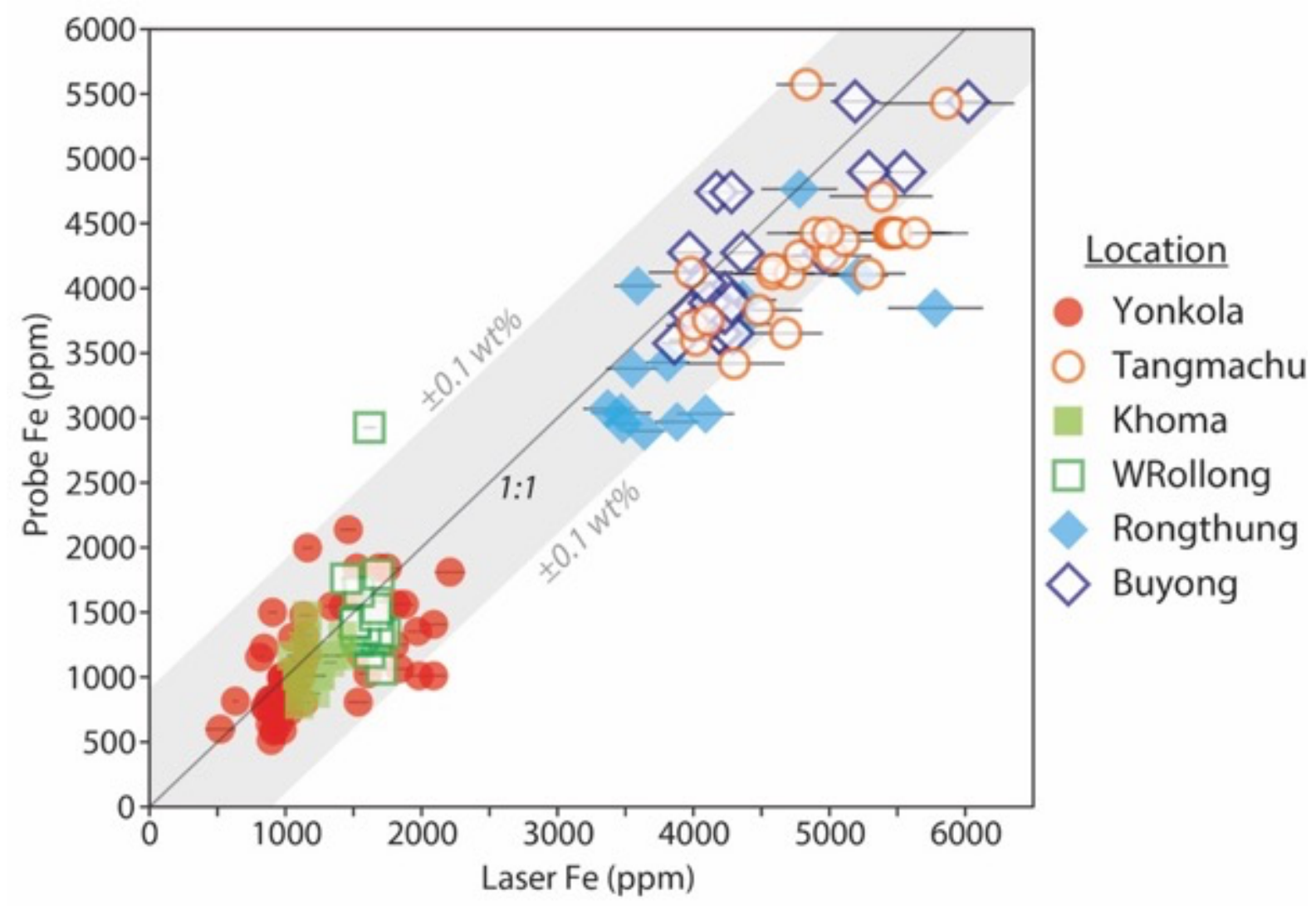

Fig. S3.1 - Comparison of Fe concentrations in kyanite analysed by LA-ICP-MS and EPMA. Errors on LA-ICP-MS analyses are $2 \mathrm{SE}$. 
S4 Full LA-ICP-MS data table as a .csv 


\section{S5 LA-ICP-MS trace element maps}

LA-ICP-MS maps were collected across 13 different grains from East Bhutan Samples. CL images (a) and V, Cr and Ge concentrations maps (b, c, d) are presented from S5.1 to S5.12.
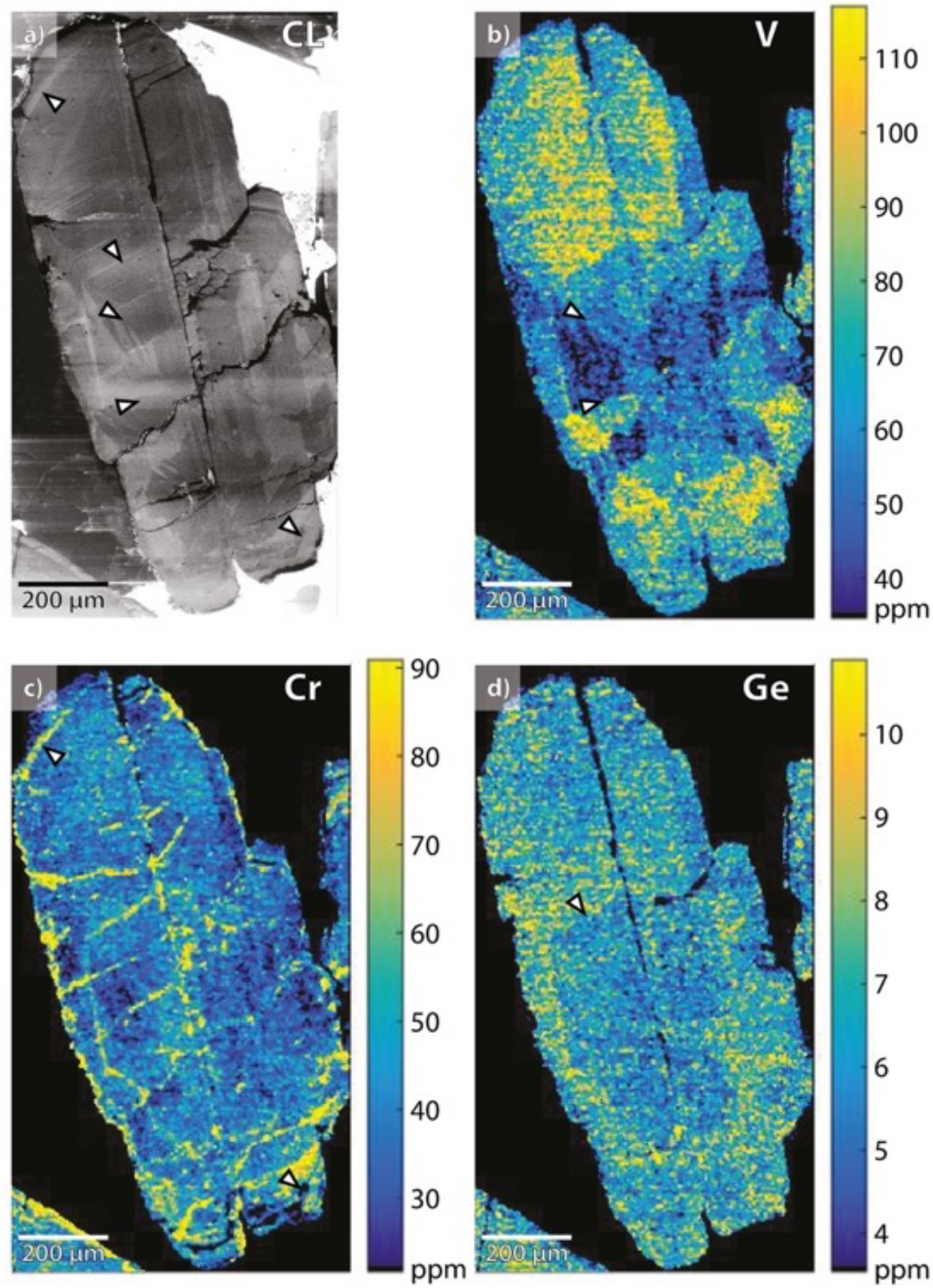

Fig. S5.1- a) Cathodoluminescence image and b)-d) LA-ICP-MS trace element maps for SPB-021x_Ky06. LA-ICP-MS maps use an auto-contrast scale, with concentrations in ppm, with a 2-median filter. 

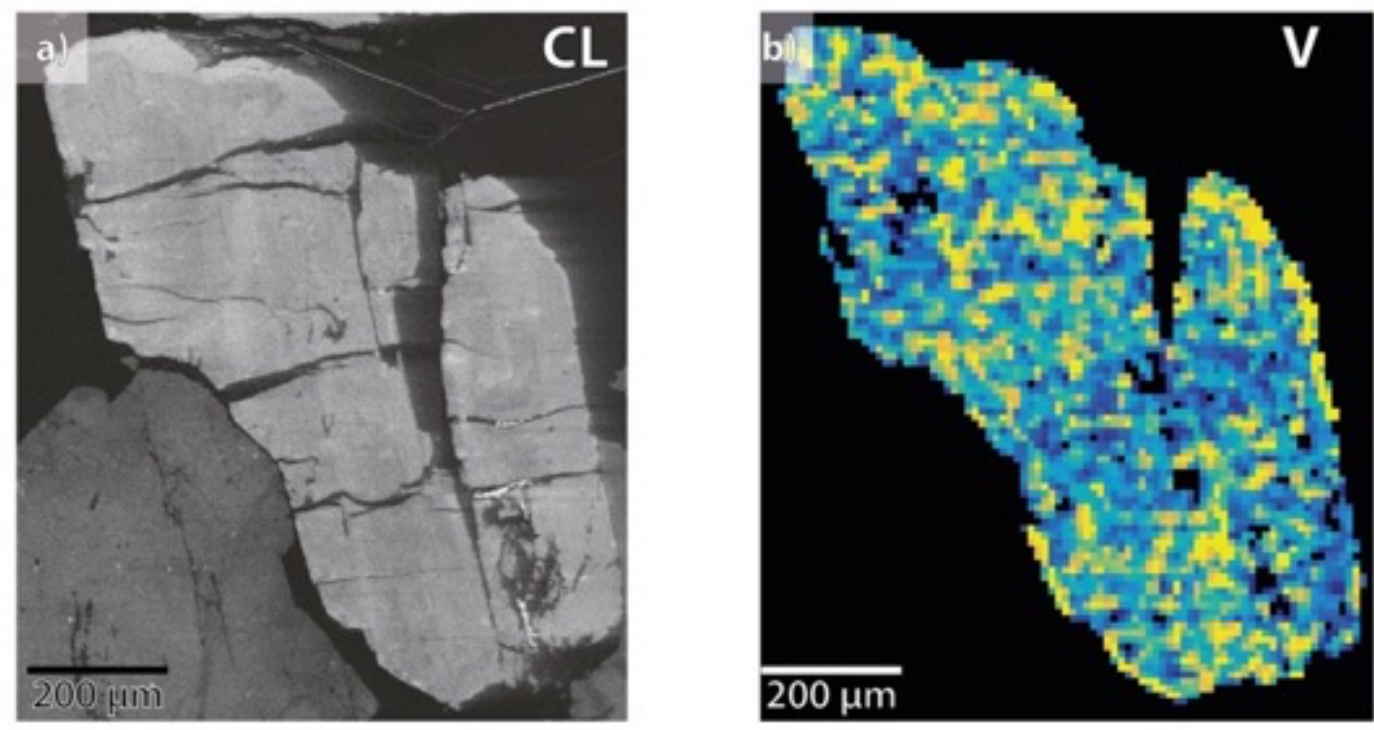

ppm
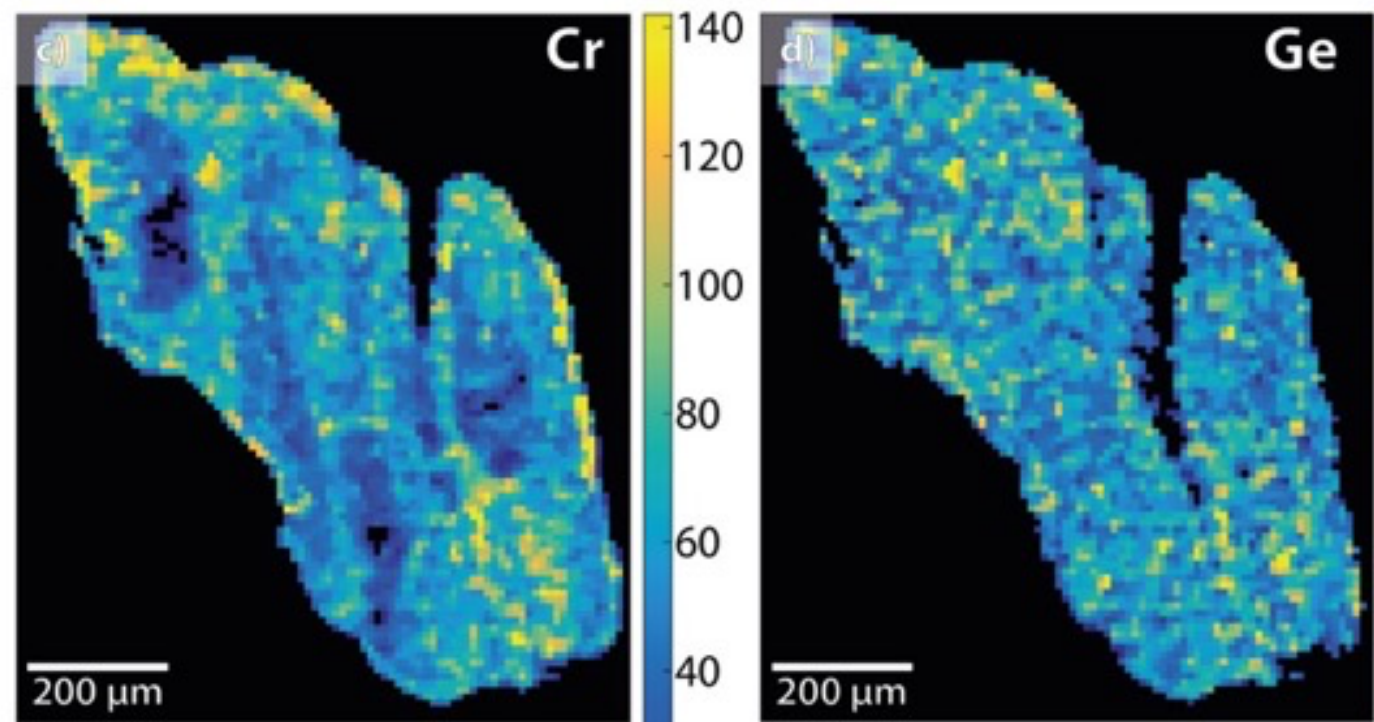

$-10$

9

8

7

80

60

40

20

3

ppm

ppm

Fig. S5.2- a) Cathodoluminescence image and b)-d) LA-ICP-MS trace element maps for SPB-021x_Ky09a. LA-ICP-MS maps use an auto-contrast scale, with concentrations in ppm, with a 2-median filter. 

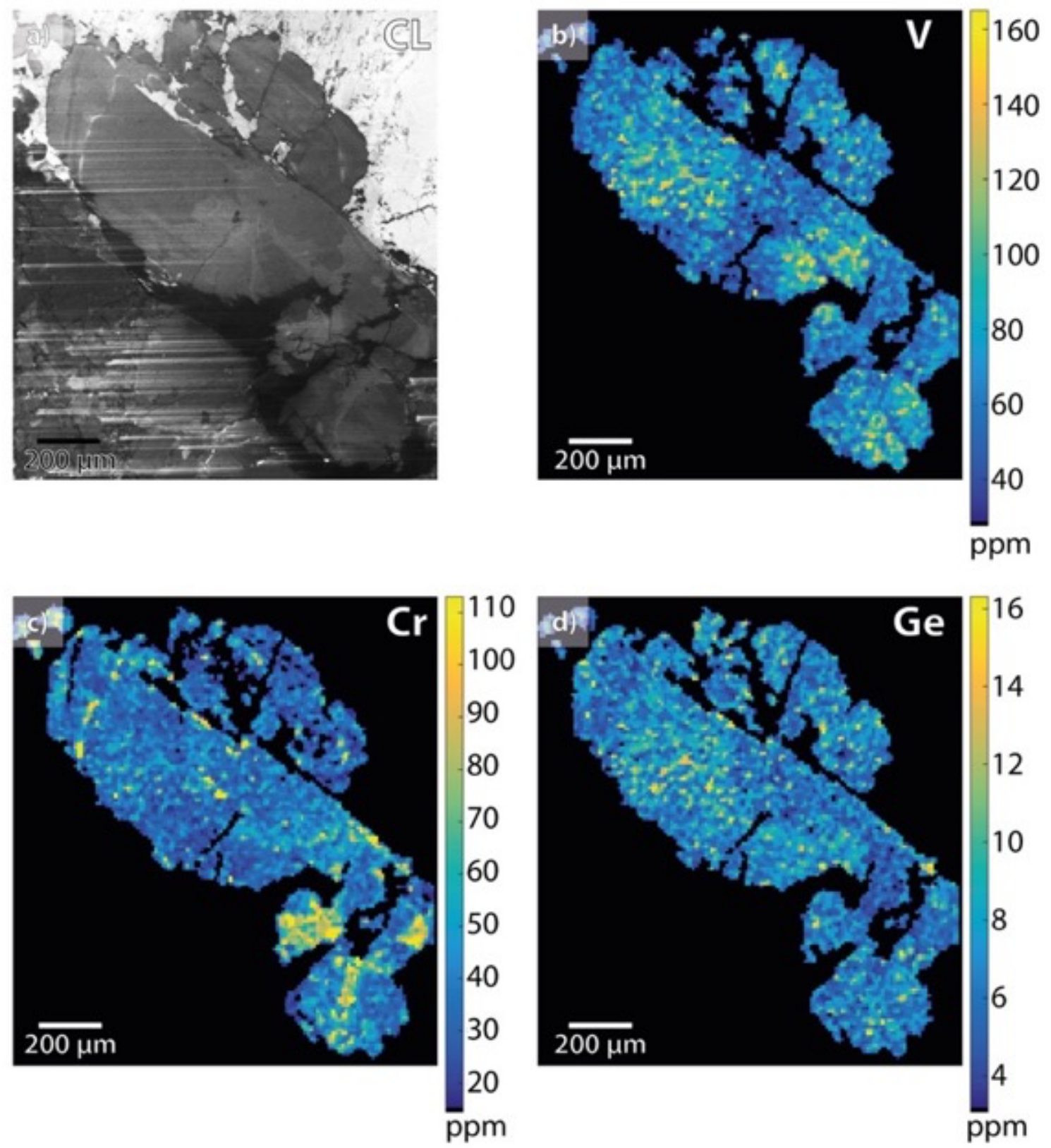

Fig. S5.3- a) Cathodoluminescence image and b)-d) LA-ICP-MS trace element maps for SPB-021x_Ky14. LA-ICP-MS maps use an auto-contrast scale, with concentrations in ppm, with a 2-median filter. 

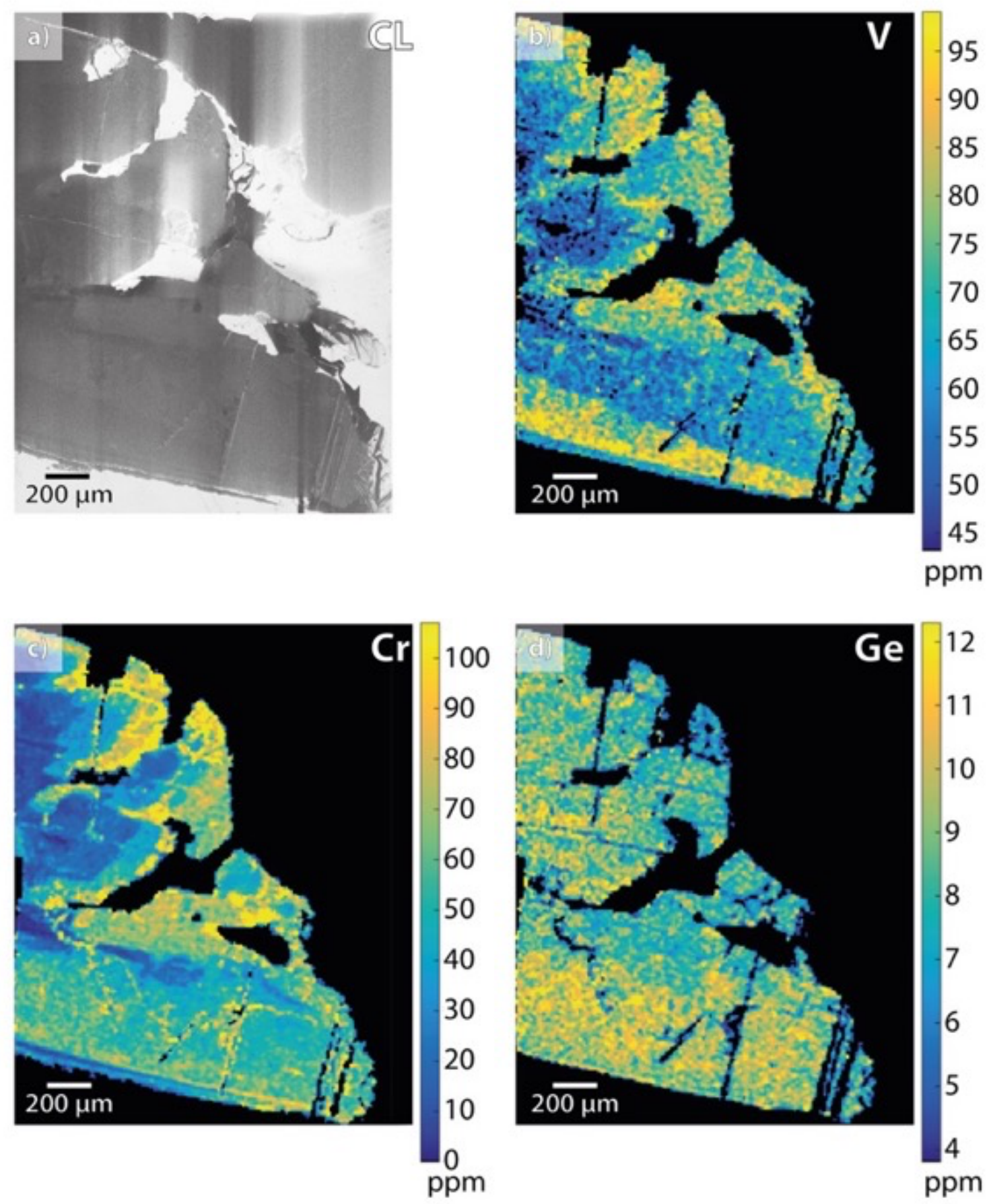

Fig. S5.4- a) Cathodoluminescence image and b)-d) LA-ICP-MS trace element maps for SPB-021xii_Ky03. LA-ICP-MS maps use an auto-contrast scale, with concentrations in $\mathbf{p p m}$, with a 2-median filter. 

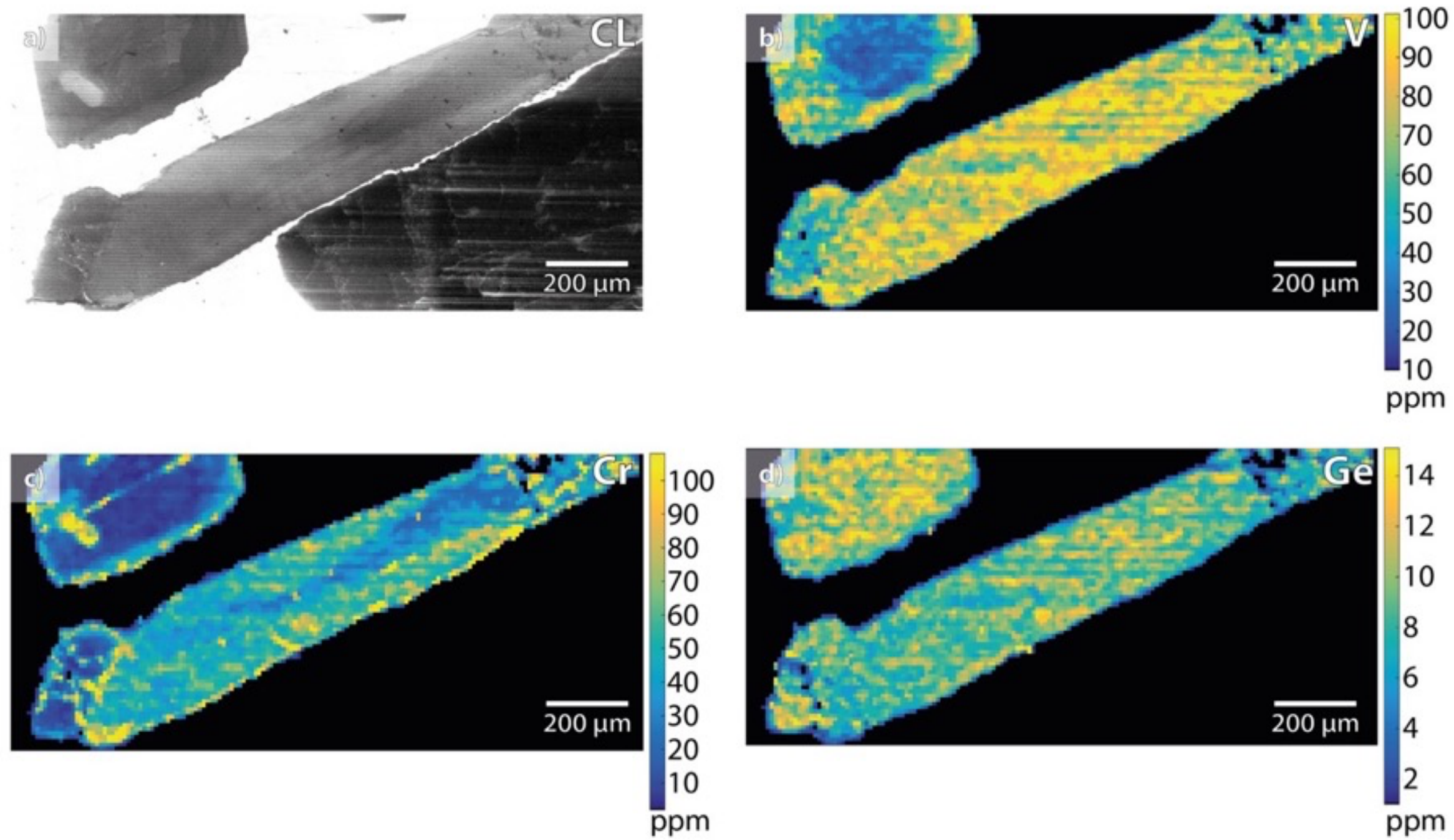

Fig. S5.5- a) Cathodoluminescence image and b)-d) LA-ICP-MS trace element maps for SPB-021xii_Ky06a. LA-ICP-MS maps use an auto-contrast scale, with concentrations in ppm, with a 2-median filter. 

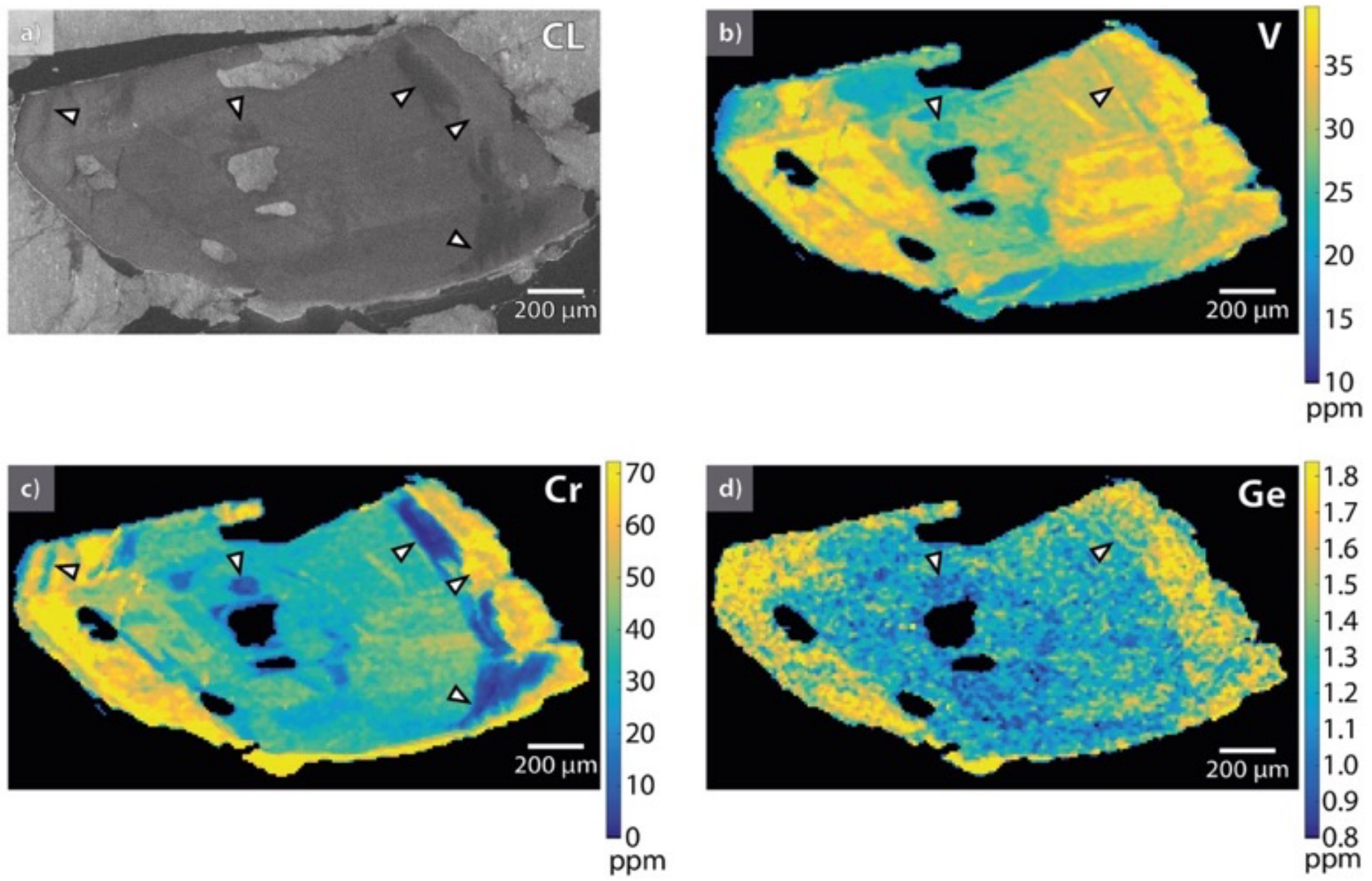

Fig. S5.6- a) Cathodoluminescence image and b)-d) LA-ICP-MS trace element maps of SPB-026bx_Ky03 grain. Arrows denote features observed in CL image that are also seen in LA-ICP-MS maps. LA-ICP-MS maps use an auto-contrast scale, with concentrations in ppm, with a 2-median filter. 

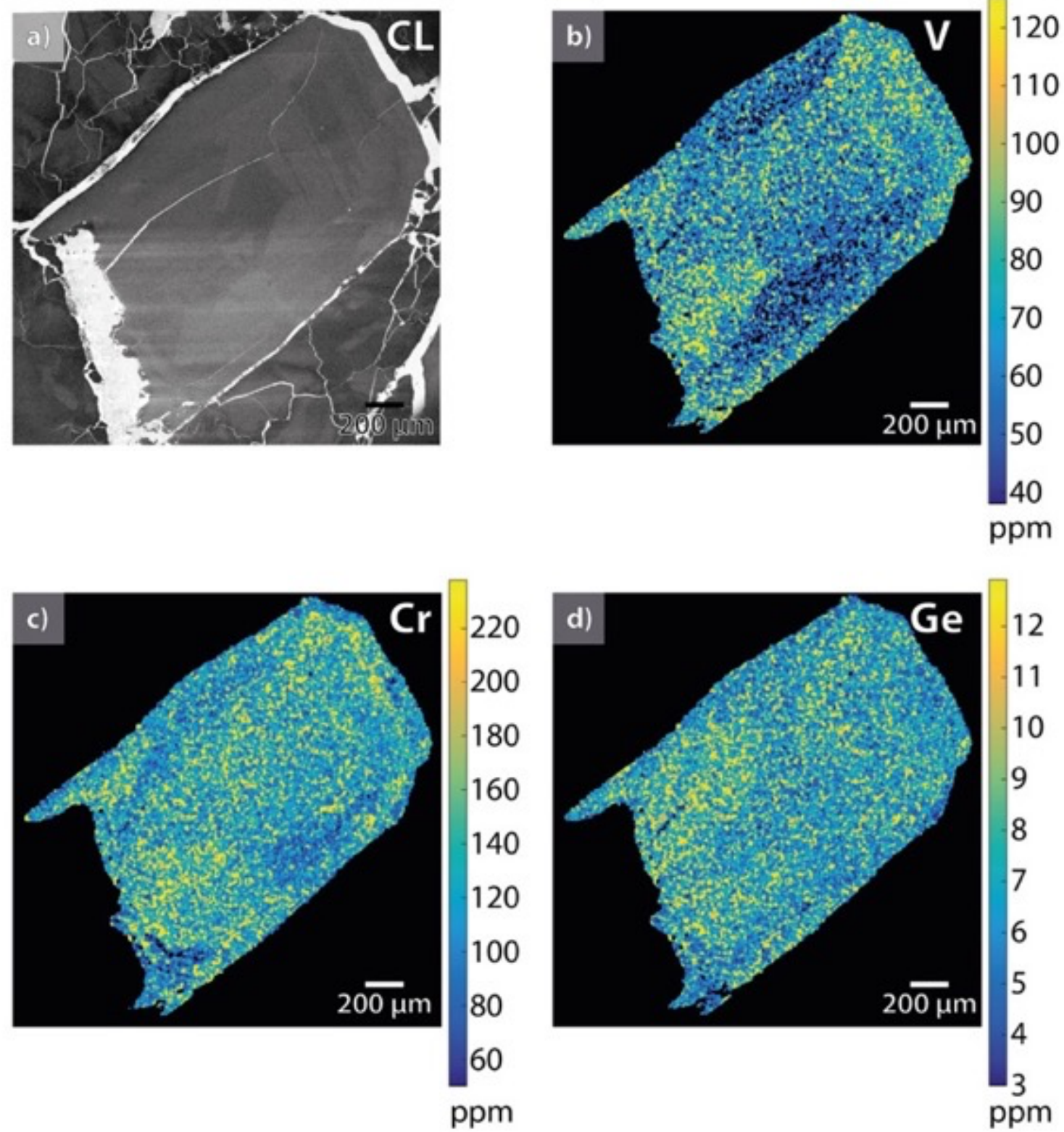

Fig. S5.7- a) Cathodoluminescence image and b)-d) LA-ICP-MS trace element maps for SPB-031_Ky11. LA-ICPMS maps use an auto-contrast scale, with concentrations in ppm, with a 2-median filter. 

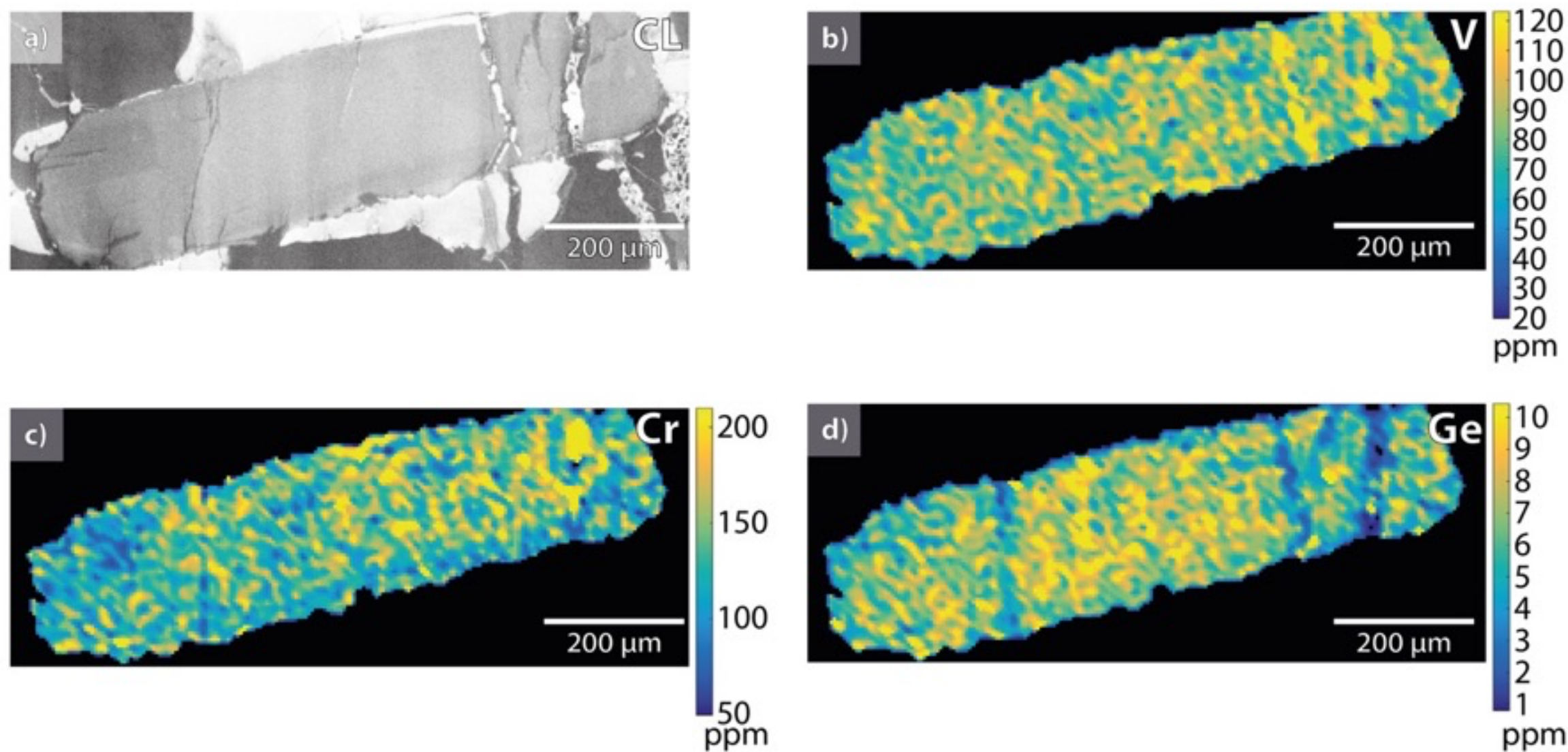

Fig. S5.8- a) Cathodoluminescence image and b)-d) LA-ICP-MS trace element maps for SPB-031_Ky15. LA-ICP-MS maps use an auto-contrast scale, with concentrations in ppm, with a 2-median filter. 

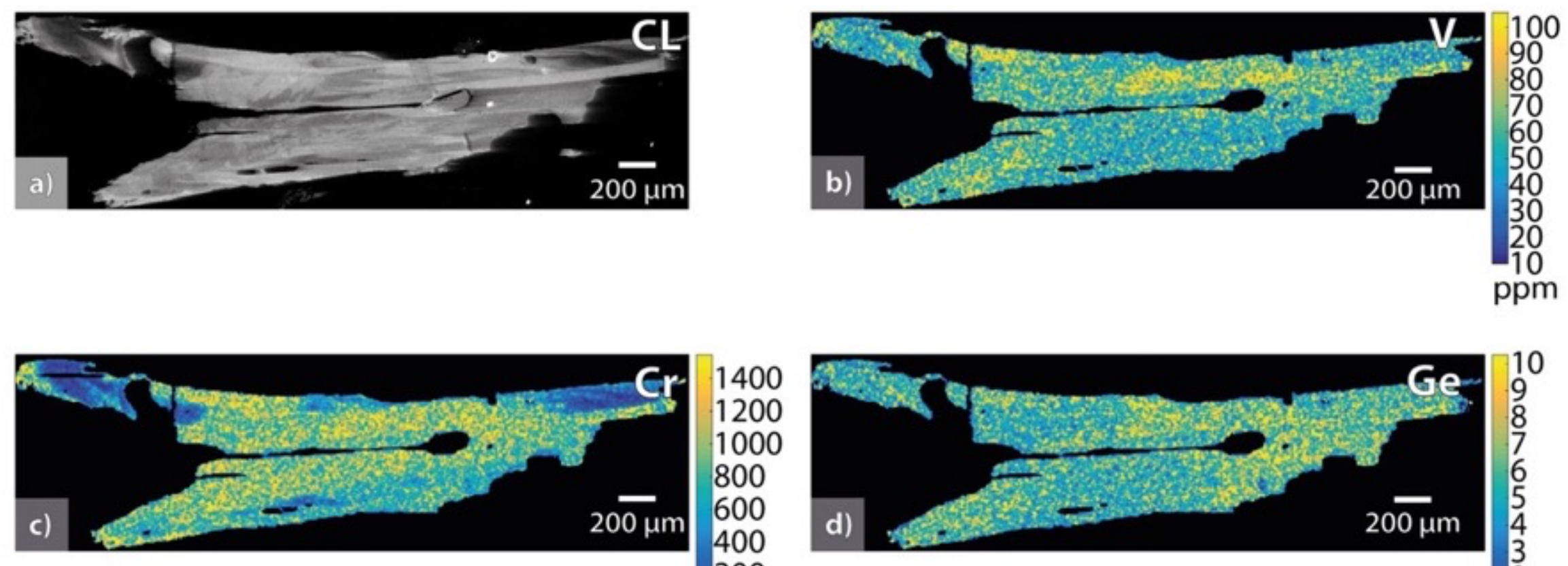

1400
1200
1000
800
600
400
200
$p p m$

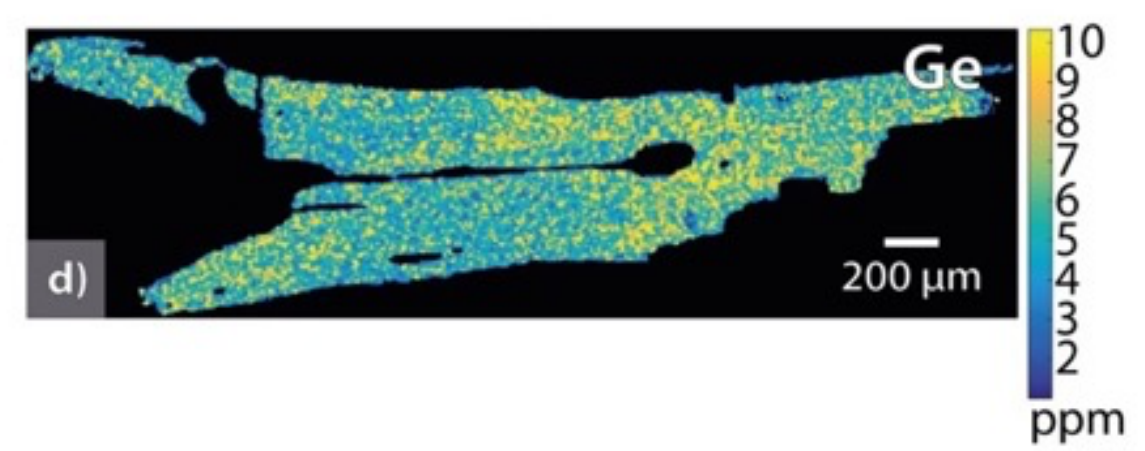

Fig. S5.9- a) Cathodoluminescence image and b)-d) LA-ICP-MS trace element maps for SPB-033_Ky04. LA-ICP-MS maps use an auto-contrast scale, with concentrations in ppm, with a 2-median filter. 

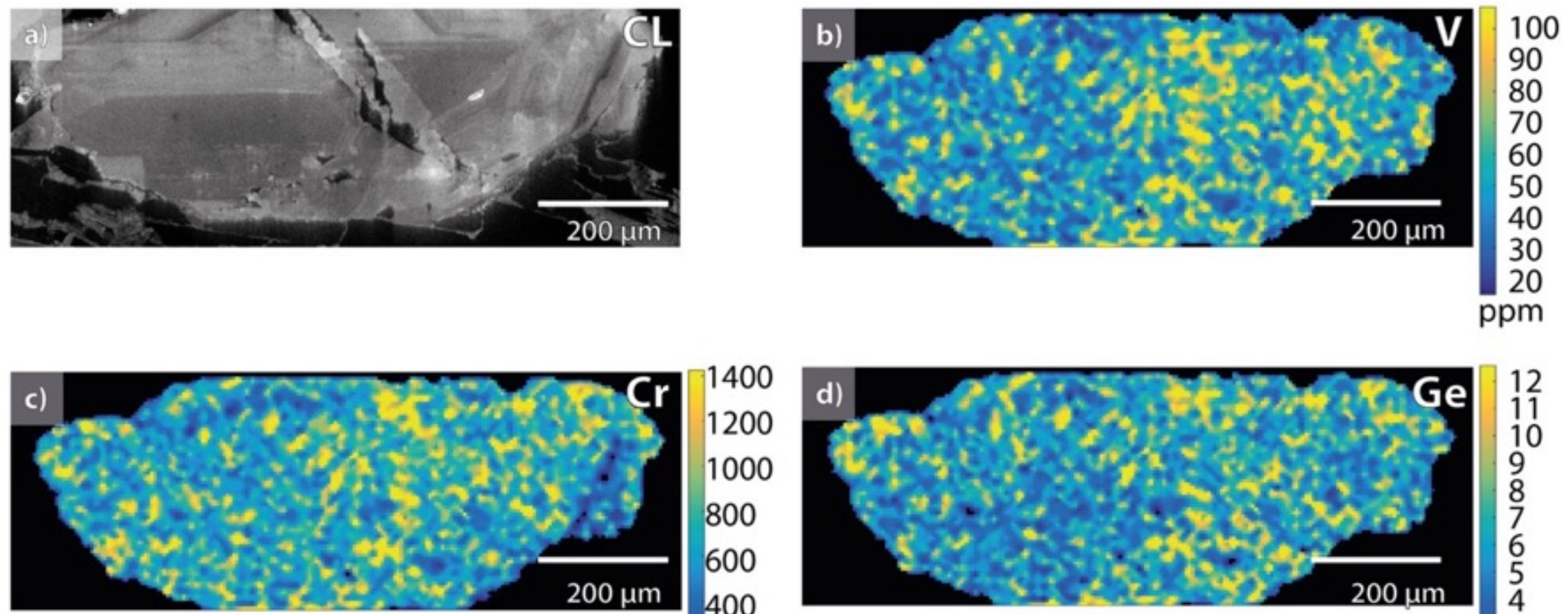

1400
1200
1000
800
600
400
200
$p p m$

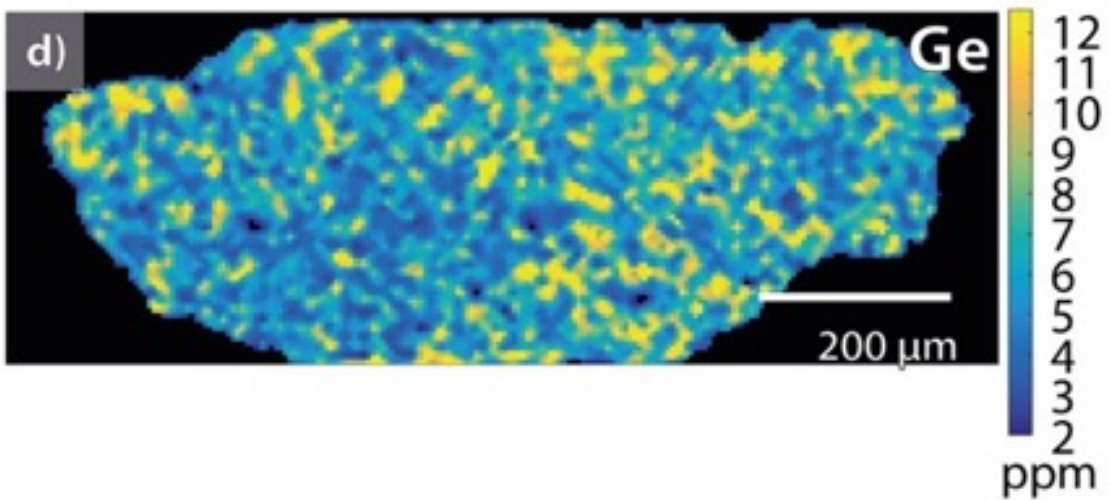

Fig. S5.10- a) Cathodoluminescence image and b)-d) LA-ICP-MS trace element maps for SPB-033_Ky12. LA-ICP-MS maps use an auto-contrast scale, with concentrations in ppm, with a 2-median filter. 

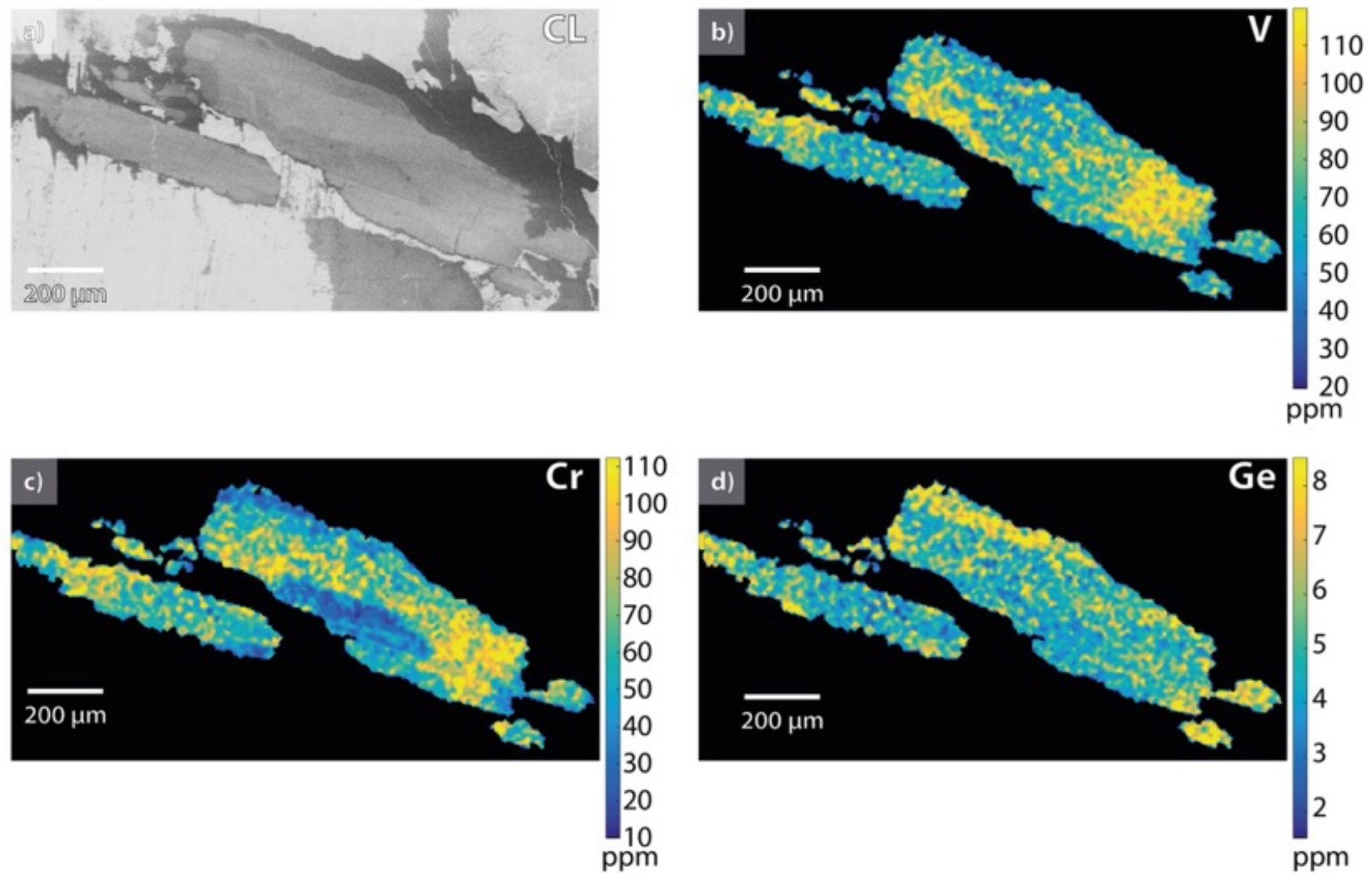

Fig. S5.11- a) Cathodoluminescence image and b)-d) LA-ICP-MS trace element maps for SPB-036_Ky19. LA-ICP-MS maps use an auto-contrast scale, with concentrations in ppm, with a 2-median filter. 

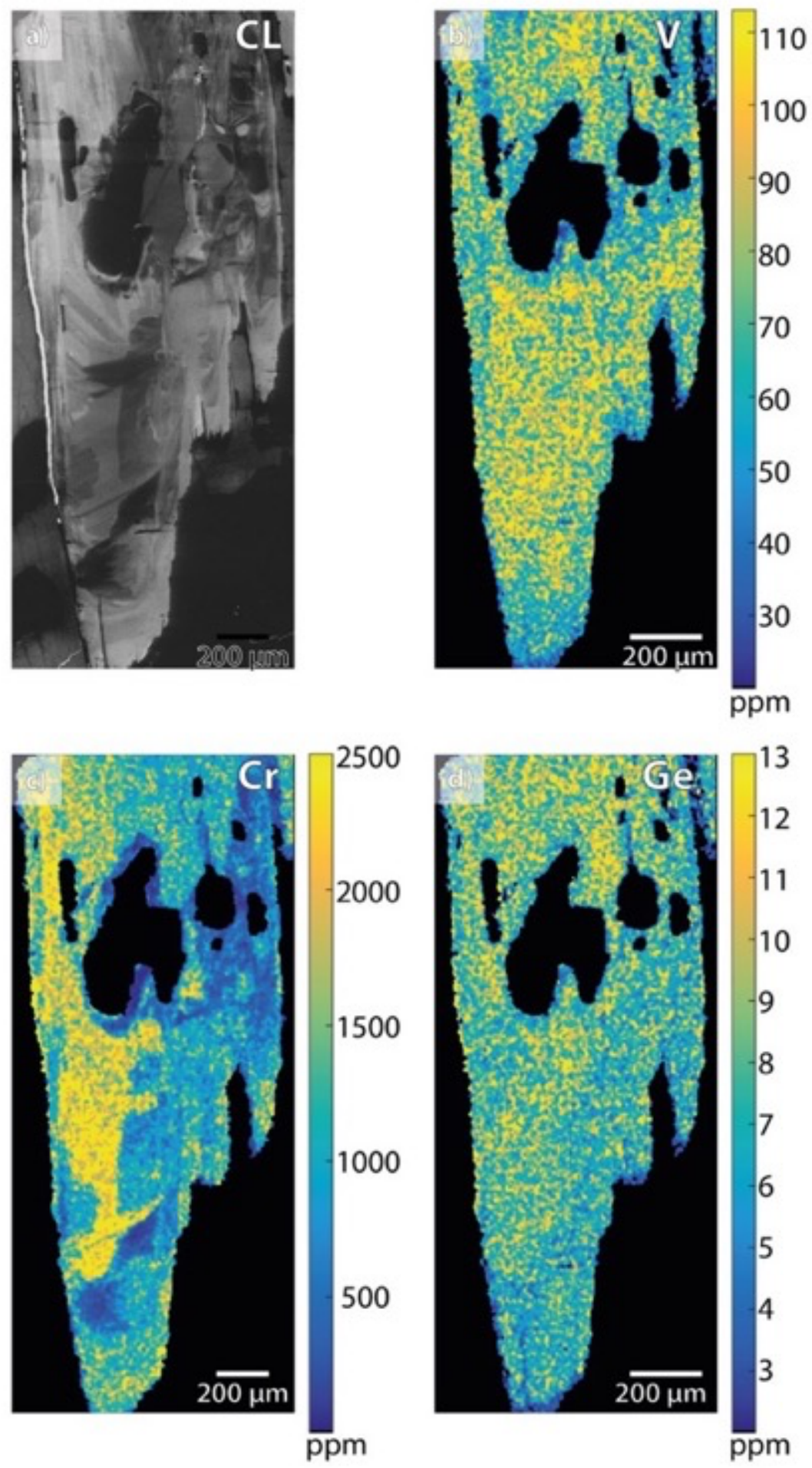

Fig. S5.12- a) Cathodoluminescence image and b)-d) LA-ICP-MS trace element maps for SPB-049i_Ky07. LA-ICPMS maps use an auto-contrast scale, with concentrations in ppm, with a 2-median filter. Note that spot size for this larger grain was $20 \mu \mathrm{m}$ instead of $10 \mu \mathrm{m}$. 


\section{S6 Comparison between LA-ICP-MS trace element maps and spot analyses}

Element concentrations measured from LA-ICP-MS map and spot analyses performed on the same grains are similar. Minor discrepancies were likely caused by 'spatial averaging' due to the larger size of the spot analyses $(40 \mu \mathrm{m})$ than the pixels on the maps $(10 \mu \mathrm{m})$.

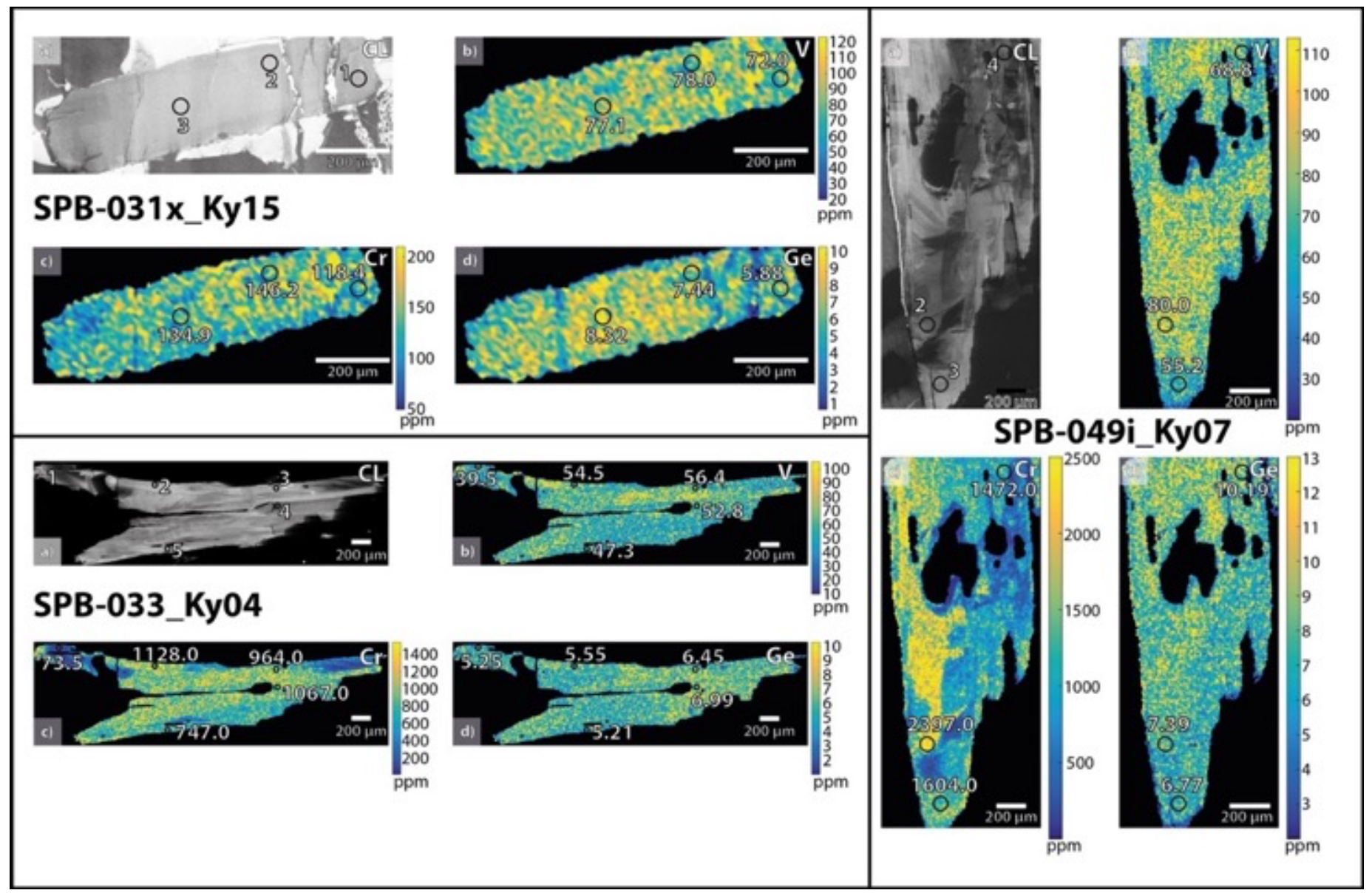

Fig. S6.1- CL images and LA-ICP-MS maps with trace element concentrations from LA-ICP-MS spot analyses of kyanite. Numbers on CL images represent Laser spot number, concentrations on maps are in ppm. 